\title{
Using a social-ecological system approach to enhance understanding of structural interconnectivities within the beekeeping industry for sustainable decision making
}

\author{
Vidushi Patel $^{1,2}$, Eloise M. Biggs $^{3}, \underline{\text { Natasha Pauli }}^{1,3}$ and $\underline{\text { Bryan Boruff }}^{1,2,3}$
}

\begin{abstract}
The social-ecological system framework (SESF) is a comprehensive, multitiered conceptual framework often used to understand human-environment interactions and outcomes. This research employs the SESF to understand key interactions within the bee-human system (beekeeping) through an applied case study of migratory beekeeping in Western Australia (WA). Apiarists in WA migrate their hives pursuing concurrent flowering events across the state. These intrastate migratory operations are governed by biophysical factors, e.g., health and diversity of forage species, as well as legislated and negotiated access to forage resource locations. Strict biosecurity regulations, natural and controlled burning events, and changes in land use planning affect natural resource-dependent livelihoods by influencing flowering patterns and access to valuable resources. Through the lens of Ostrom's SESF, we (i) identify the social and ecological components of the WA beekeeping industry; (ii) establish how these components interact to form a system; and (iii) determine the pressures affecting this bee-human system. We combine a review of scholarly and grey literature with information from key industry stakeholders collected through participant observation, individual semistructured interviews, and group dialog to determine and verify first-, second-, and third-tier variables as SESF components. Finally, we validate the identified variables through expert appraisal with key beekeepers in the industry. Our results identify the governance system, actors, resource system, and resource units comprising the beekeeping industry in WA. Using this approach, we identify three principal system pressures including access to apiary sites, burning of forage, and climate change impacts on the system, which influence the SES and its sustainability. Our approach provides for an improved understanding of SES complexities and outputs that should be used to support improved sustainable management of common pooled resources to ensure effective pollination and sustained apiary production.
\end{abstract}

Key Words: local ecological knowledge; migratory beekeeping; social-ecological system; sustainability

\section{INTRODUCTION}

Bees and beekeeping have recently received significant attention for their contributions to sustainable development (Carroll and Kinsella 2013, Yap et al. 2015, Minja and Nkumilwa 2016, Klein et al. 2018, Vinci et al. 2018, Dangles and Casas 2019, Patel et al. 2020) and human well-being (Gill et al. 2016, IPBES 2016, Sánchez-Bayo and Wyckhuys 2019). Beekeeping involves the production of honey and other bee products as well as crucial pollination services (Pilati and Prestamburgo 2016). For more than 15,000 years, the reciprocal relationship between Apis mellifera (the European honeybee ${ }^{[1]}$ ) and Homo sapiens has resulted in mutually beneficial outcomes (Lehébel-Péron et al. 2016), yet the interconnectedness between these two species has only been partially explored. Initial exploration of this relationship has used a social-ecological system (SES) approach to address resource management and sustainability of wild beehuman systems (Matias et al. 2017). Yet, to our knowledge, an SES approach has not been applied to managed bee-human systems, i.e., the beekeeping industry. The honeybee-human system is unique, and like those ecosystems supporting wild bee populations, it is equally vulnerable to adverse resource management decision making (Aizen and Harder 2009, Potts et al. 2010, vanEngelsdorp and Meixner 2010).

The sustainability of a beekeeping system depends on continuous access to quality forage resources for bees to maintain healthy and productive colonies (Pilati and Fontana 2018). To access forage resources, many beekeepers, such as those in Europe and the United States of America, migrate their hives following honey flows across public and private lands (Pilati and Prestamburgo 2016, Durant 2019). Access to forage sites are often dependent on permission from authorities or through negotiation with private land owners (Hill et al. 2019). Ad hoc changes in management approaches on both private and public lands can limit access to important natural resources and impact beekeepers' livelihoods. Furthermore, because bee foraging is a landscape-scale process (Sponsler and Johnson 2015), the impact of change in landscape composition is axiomatic in the case of migratory beekeeping (Malkamäki et al. 2016, Smart et al. 2016, Galbraith et al. 2017, Evans et al. 2018).

Complex natural and anthropogenic drivers are contributing to global bee decline (Goulson et al. 2015, Wagner 2020) and are impacting on bee system contributions that support sustainable development (Patel et al. 2020). Evidence also suggests that negative interactions can occur between wild and managed bees, including resource competition, disease transmission, and plantpollinator network disruption (Geslin et al. 2017, Mallinger et al. 2017, Valido et al. 2019). As global agricultural landscapes have become less diverse and increasingly reliant on pollinators (Aizen et al. 2019), a rise in the number of managed bee colonies has occurred to cope with the pollinator deficit (as highlighted in Aizen and Harder 2009). As a result, an increase in interactions between domestic and with wild bee populations may occur.

${ }^{1}$ UWA School of Agriculture and Environment, The University of Western Australia, Crawley, WA, Australia, ${ }^{2}$ Cooperative Research Centre for Honeybee Products (CRCHBP), Yanchep, WA, Australia, ${ }^{3}$ Department of Geography and Planning, The University of Western Australia, Crawley, WA, Australia 
However, safeguarding both wild and managed bees is critical for food production and to address wider sustainability challenges, targeted approaches that adopt a bee-human system perspective (Kleijn et al. 2018, Saunders et al. 2018, Patel et al. 2020) are required. Bee-human system sustainability implies maintaining broader bee biodiversity to ensure a sustainable supply of beemediated services (Patel et al. 2020).

A social-ecological systems approach provides a lens through which the bee-human relationship can be examined. To date, research has primarily focused on the benefits humans receive from bees (Bradbear 2009, Carroll and Kinsella 2013, Klein et al. 2018) rather than the reciprocal relationship between the two species. Using an SES framework, both human and natural systems can be examined in equal depth (Binder et al. 2013), providing a mechanism for understanding the complex interdependencies between the various components of both systems. Importantly, the complex feedbacks between social and ecological components contribute to the management of ecosystem service (ES) flows (Rova and Pranovi 2017). Applying an SES approach to the bee-human system allows for the identification and management of system drivers, activities, and processes that contribute to the sustainable development of the system (Matias et al. 2017) through improved environmental management and governance (Rodela et al. 2019). As such, our research aim is to characterize the beekeeping industry as an SES through identification of human and biophysical components, associated interactions, and key beekeeping processes. Acquired novel understanding of the complex interconnectivities associated with the beekeeping SES will enable facilitated management of system pressures, i.e., the availability, access, and utilization of apiary sites, and help inform integrated policy design to achieve sustainable development that is inclusive of biodiversity conservation.

\section{Social-ecological system framework (SESF)}

In this research, we focus on conceptualizing beekeeping as a social-ecological system through the lens of Elinor Ostrom's SES framework (SESF; McGinnis and Ostrom 2014), using the beekeeping industry of Western Australia (WA) as an applied case study. Ostrom's SESF was primarily designed for application to management situations in common pool resources where humans are accountable for sustainable extraction and maintenance of resources (McGinnis and Ostrom 2014, Rodela et al. 2019). The framework represents a hierarchy of multitiered interacting components under six core concepts representing the first tier; resource systems (RS), resource units (RU), governance systems (GS), actors (A), interactions (I), and outcomes (O). The core concepts are nested within the broader social, ecological, and political setting $(\mathrm{S})$ accounting for feedback from, to, and between other ecosystems (Ostrom 2009, Ostrom and Cox 2010, McGinnis and Ostrom 2014). Each core concept is decomposable into a number of lower tiers, which can dictate local data collection (Ostrom 2009, Hinkel et al. 2015, Partelow 2016) for monitoring and guiding management of the system.

Ostrom's SESF has been applied to resource sectors such as forestry, irrigation, agriculture, fisheries, and watershed management (Partelow 2018). Although the framework represents bidirectional links between social and ecological systems, variable development in SESF applications has disproportionately focused on social system variables (Partelow 2018), with fewer applications adding ecological system variables (Vogt et al. 2015). Additionally, limited research has identified variables for local-level analysis (Delgado et al. 2012), those that have targeted variables to match with common terminology of the application being studied, such as socio-technical systems (Acosta et al. 2018). The uniqueness of some lower tier variables to specific sectors requires sector-specific SESFs (Basurto et al. 2013, Partelow 2018), either developed vertically by adding lower tiers under existing concepts, e.g., sea-bed tracts as a lower tier within benthic small-scale fisheries (Basurto et al. 2013), or horizontally by adding sector-specific first tier concepts, e.g., addition of transformation systems and products specific to food systems (Marshall 2015). In either approach, defining each variable relevant to the sector can improve transferability of the SESF.

Following conceptual guidance provided by Hinkel et al. (2015) and ontological logic suggested by Frey and Cox (2015), we focus on applying Ostrom's SESF for the beekeeping sector using migratory beekeeping in WA as an applied example. We advocate that our approach can be used to improve environmental management through identification of key processes involving human and biophysical components, to help ensure the long-term sustainability of the bee-human system. Our research identifies the key interactions important for understanding how various pressures can manifest across the bee-human system. To address the research aim, we explore the following questions: (i) what are the social and ecological components of the beekeeping industry; (ii) how do these components interact to form a system; and (iii) what pressures are affecting the bee-human system? We achieve this through application to the beekeeping industry of WA.

\section{METHODS}

\section{Study location: Western Australia}

The beekeeping industry of WA is characterized by clean and healthy colonies of the European honeybee (Apis mellifera), devoid of the pests and diseases that affect bee health in nearly all other parts of the world (Chapman et al. 2008, Gordon et al. 2014). Although the European honeybee is an introduced species in $\mathrm{WA}^{[2]}$, the beekeeping industry relies on native flora, especially eucalypt species, across a mosaic landscape of forest, woodlands, shrublands, and heathlands (Benecke 2007, Arundel et al. 2016). Australia has a diverse native bee fauna, and concerns have been raised as to whether introduced honeybees may compete with native bees for floral resources and/or nesting sites, or affect reproduction in native plants (Paini and Roberts 2005). A recent global review identified a range of evidence detailing adverse effects of managed bees on native bees (Mallinger et al. 2017), but within Australia there is insufficient evidence available to evaluate whether Apis mellifera has broad adverse effects on native bee species' survival or reproduction (Paini 2004, House of Representatives Standing Committee on Primary Industries and Resources 2008, Batley and Hogendoorn 2009). Because the European honeybee has been managed and naturalized in Western Australia for many decades, it is possible that the initial wave of adverse ecological effects has passed undocumented.

The majority of WA's honey-producing landscapes are geographically restricted to the Southwest Australian Floristic 
Fig. 1. The bee industry of Western Australia indicates an increasing temporal trend in both the total number of beekeepers and those practicing commercially (beekeepers who own $>50$ hives; graph). However, state production is constrained to the Southwest Australian Floristic Region (SWAFR), where there is a high density of permits issued for apiary sites (map). Beekeeping is migratory, following the year-round availability of high quality forage species (chart: species are Banksia, or eucalypts from the genera Eucalyptus and Corymbia), with jarrah, marri, and Banksia (photos) the key species targeted by Western Australia beekeepers. There are 60 species of Banksia in the southwest region, with varying flowering phenologies; beekeepers rely on Banksia species during times when eucalypts are not flowering. Data were sourced from the Department of Biodiversity Conservation and Attractions (apiary sites), Interim Biogeographic Regionalisation for Australia (used to delineate biogeographic regions), Australian Bureau of Statistics (state boundaries), and Bureau of Meteorology (used to identify Noongar flowering calendar).

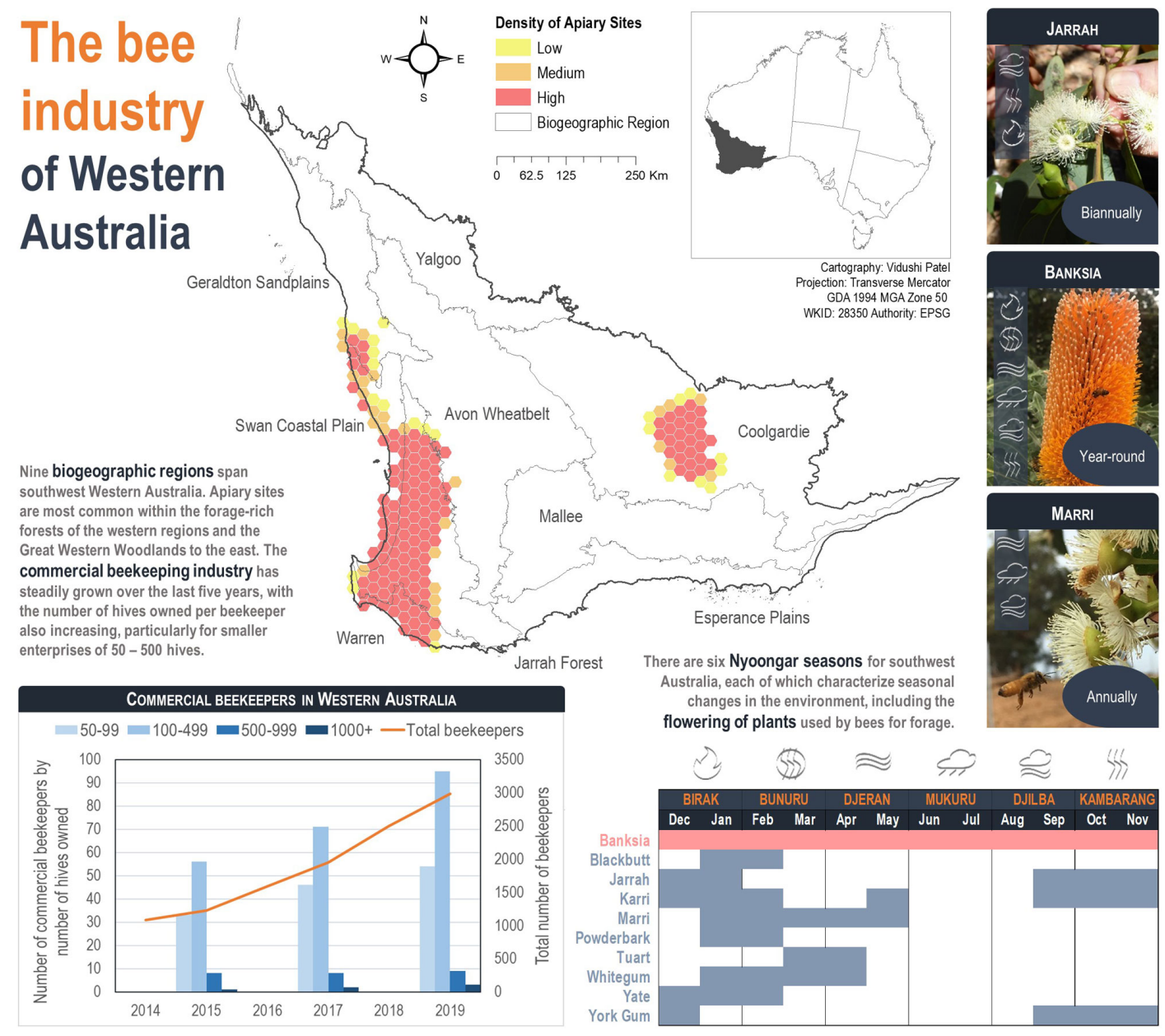

Region (SWAFR; Smith 1969, Gibbs and Muirhead 1998, Benecke 2007, Roshan et al. 2017). Changes in weather and lifestages of flora and fauna across the region are best characterized using the six seasons described by the traditional custodians of the land, the Noongar (Fig. 1). Specifically, forested areas are sought after for polyfloral and monofloral honey production. In WA, forest and woodland stands dominated by jarrah (Eucalyptus marginata) and marri (Corymbia calophylla) are coveted for monofloral honey production, given higher revenue potential because of the honey's unique flavor, texture, and medicinal properties (Roshan et al. 2017, Soares et al. 2017; Fig. 1).
Apiarists in WA migrate their hives between two to six times per year following the sequence of flowering events across the state (because the timing of peak flowering varies with species and location), traversing a mix of private and leased public sites in the process (Somerville and Nicholson 2005, Gordon et al. 2014). Usage of each site lasts between two weeks and a few months depending on variability in active flowering and nectar production. The success of each migration sequence is dependent on the quality of the individual site accessed (Somerville and Nicholson 2005, Pilati and Prestamburgo 2016). Foraging resources are primarily located on government-managed land, including state forest, national parks, and nature reserves, which 
together account for more than $75 \%$ of the state's honey production (Gibbs and Muirhead 1998, Crooks 2008). Over the past decade, $31 \%$ of beekeepers have reported reductions in the use of public land because of restricted site access in response to changing government policies (van Dijk et al. 2016).

The beekeeping industry is growing rapidly in WA. Similar to all livestock owners, beekeepers are required to register with the Department of Primary Industries and Rural Development (DPIRD). According to data sourced from DPIRD, between 2015 and 2019 the total number of registered beekeepers more than doubled, with a $64 \%$ increase in commercial beekeeping (defined as more than 50 hives) over the last five years (Fig. 1). Demand for forage sites to host apiaries has also increased responding to industry growth. As of 2018, 4479 site licenses were made available by the Department of Biodiversity Conservation and Attractions (DBCA), and of these, 70\% were located within the SWAFR (Fig. 1).

Although sites on private land are often used for free or in exchange for honey products, sites on public land require the issue of a lease (subject to renewal every seven years) and vegetation clearing approvals (if clearing is required). Beekeepers request a permit from DBCA to site their apiaries. The requested site coordinates are then sent to the relevant local government for assessment against a series of criteria before sanctioning an apiary permit for hive placement within $500 \mathrm{~m}$ from the approved coordinates. Reporting the duration of site use to DBCA is mandatory for monitoring resource use. Spatial overlap of apiary permits with other land tenure may result in additional negotiation with existing lease owners (Salvin 2015), which adds a multifunctional aspect to resource management for beekeeping.

In addition to managing resource access, the beekeeping industry is facing numerous challenges. There is an increasing risk of pest and disease attacks (Crooks 2008, Phillips 2014) despite strict biosecurity regulations. Extensive agriculture and urbanization have resulted in the removal of nearly $80 \%$ of the extent of native vegetation in southwest WA since 1910 (Phillips et al. 2010, Andrich and Imberger 2013, Shedley et al. 2018). Land clearing has likely contributed to reduced precipitation (Pitman et al. 2004, Andrich and Imberger 2013) and altered groundwater levels (Dawes et al. 2012), which have adversely affected the biodiversity of the region (Brouwers et al. 2013, Mastrantonis et al. 2019). The declining trend in precipitation since 1970 is projected to continue into the future (Hughes 2011, Smith and Power 2014, Pettit et al. 2015), which has implications for survival and distribution of forage resources. For example, drought can have an adverse impact on the growth and flowering of melliferous (nectar-producing) flora (Benecke 2007). Soil-borne Phytophthora dieback is affecting important species used to produce honey, such as karri (Eucalyptus diversicolor) and jarrah (Benecke 2007). And last, changing land regulations such as an increase in conservation areas has affected beekeepers' access to their traditional resource base (Benecke 2007).

Given these collective challenges, there are many necessary critical management and governance considerations to ensure the longterm viability of the ecosystem services obtained from beekeeping activities while conserving broader biodiversity. Characterizing the WA beekeeping industry using Ostrom's SESF is a step toward providing a more informed bee-human structural framing to support collective action (Phillips 2014) and a transition toward strategic environmental decision making (McGinnis and Ostrom 2014, Elsawah et al. 2015, Partelow et al. 2019).

\section{Employing the SESF for the beekeeping industry}

Identifying and defining important SESF variables and feedback amongst variables required a mixed-methods approach. We conducted qualitative research following a diagnostic procedure suggested by the SESF literature (Ostrom and Cox 2010, Hinkel et al. 2015, Partelow et al. 2018a) to prepare an initial list of second tier variables that built upon the first tier concepts (Fig. 2) for the beekeeping SES. Although literature to guide the variable development process was scant (Partelow et al. 2018b), sufficient information from other applications of the framework was available to guide direction of the SESF for establishing multitier variables (Ostrom 2009, McGinnis and Ostrom 2014, DelgadoSerrano and Ramos 2015, Vogt et al. 2015), build ontology for new concepts (Frey and Cox 2015), and apply to the bee-human system (Nagendra and Ostrom 2014, Acosta et al. 2018, Partelow et al. 2018b, Johnson et al. 2019, Ovitz and Johnson 2019). The initial literature-informed list was further refined and updated to include third and fourth tier variables, and subsequently validated using various local stakeholder engagement activities. For each phase of data collection, key SESF literature including McGinnis and Ostrom (2014), Delgado-Serrano and Ramos (2015), Hinkel et al. (2015), Vogt et al. (2015), and Partelow (2018) was used to guide the collation and refinement of SESF variables. Further details on references and methods for each SESF variable which was ultimately defined are provided in Appendix 1.

\section{Preparing the initial list of variables}

To prepare the initial list of variables, a desktop analysis of government reports, news articles, policy documents, and relevant industry communications was conducted and key terms were listed under each first tier concept. For example, tree plantation, native forest, and weeds on roadsides were listed under "Resource System" from government reports on commercial beekeeping in Australia (Benecke 2007, Goodman 2014). Similar to Phillips (2014), participant observation, collected through attendance at meetings of beekeeping organizations, conferences, and industryorganized community engagement activities, was used to list additional terms under each concept. Archival and observational assessment information was then cross-referenced with other applications of the SESF applications such as fisheries (Basurto et al. 2013, Leslie et al. 2015) and aquaculture (Partelow et al. $2018 b$ ) so that the listed terms could be identified as an existing variable or a new variable. To refine the variable list, semistructured interviews with key industry stakeholders were conducted. Verification of variables was then performed with industry experts within a focus group discussion session. Following verification, variables were independently validated by expert retired beekeepers within a focus group discussion session. This process of variable refinement, verification, and validation followed a multimethod iterative stakeholder engagement approach (outlined in Table 1), similar to that used by Johnson et al. (2019).

\section{Refinement of the initial list of variables}

For variable refinement using semistructured interviews with key industry stakeholders, participants were recruited using a snowballing technique centered on circulation of a volunteer 
Fig. 2. Conceptual diagram of the social-ecological system for the beekeeping industry guided by Ostrom (2009). This illustrates the Tier 1 components of the social-ecological system framework, comprising bee habitat (resource system), managed hives (resource unit), organizations (governance system), commercial beekeepers (actors), hive migration (interactions), and apiary production (outcomes).

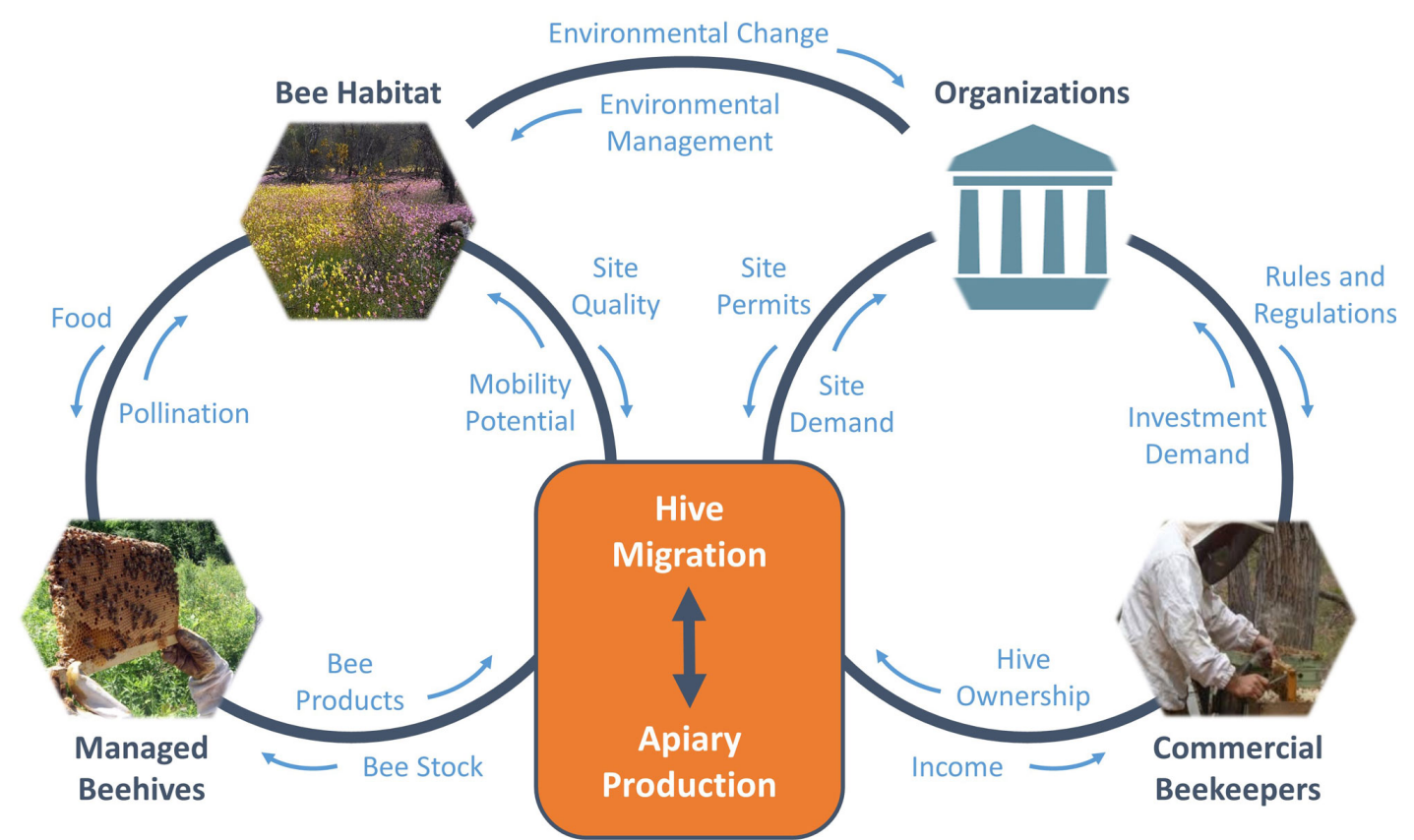

request flyer via social media, word of mouth, and through advertisement by the Beekeeping Industry Council of Western Australia (BICWA). Using a similar approach to Malkamäki et al. (2016), two question guides were developed, reflecting the broad themes identified through the initial variable preparation process (Appendix 2), and used to conduct semistructured interviews (duration: 35-50 minutes) during 2017 and 2018 with 29 commercial and semicommercial beekeepers. This participant sample represents approximately one-fifth of the beekeeping industry in $\mathrm{WA}^{[3]}$ who are major contributors to the total honey production of the state. Sampling was stopped upon saturation where no additional information was collected from participants. Two representatives from governing organizations were also interviewed. All 31 participants provided written consent for undertaking the interviews.

\section{Verification of refined variables}

Experts actively engaged with the beekeeping industry in WA were asked to form part of an advisory group ${ }^{[4]}$. An open-ended discussion session was conducted with the advisory group members regarding the initial and refined lists of variables. Different approaches for open-ended discussion were used because of time commitments of the members; four members met with the lead researcher together in a group setting, and the remaining two members met with the lead researcher individually (during October 2018).

\section{Validation of variables and identification of key feedback within the system}

Because experienced beekeepers hold deep local knowledge of bee systems (Galbraith et al. 2017, Uchiyama et al. 2017), a full- day workshop was conducted with six retired beekeepers (December 2018; Fig. 3), whose involvement in beekeeping spanned 30 to 60 years, to undertake independent validation of the verified SESF (Stojanovic et al. 2016; note, active commercial beekeepers with similar experience were unable to commit for the day-long workshop). This validation stage was independent because no leading information was provided to participants. A professional moderator was used to mediate the activities to avoid researcher bias in the process (Knapp et al. 2011). The first activity of the workshop required participants to list all environmental and human aspects deemed necessary to the functionality of the beekeeping industry. Subsequently a mind mapping exercise was perform to harness key interconnectivities across the industry. To refine the initial mind map further, discussion was prompted using 30 keyword cards covering broad SESF themes (e.g., "plants"); this was to ensure participants had considered all the system components for which validation was required. Any discussion by participants concerning system pressures was listed throughout the workshop by a second session moderator who did not engage in the workshop adjudication (this was the lead investigator). Following the mind map generation, the lead moderator then requested participants to add any system pressures that had been noted by the second moderator to the system mind map; an open discussion then refined these ideas. After all four activities were completed, participants were invited to ask questions to the lead investigator and lead moderator regarding the broader objectives of the research.

Based on this iterative data collection process, variables were identified to provide a foundation for applying the SESF to the beekeeping industry. The system variables and interconnectivities 
Table 1. Summary of methods used to seek information from stakeholder groups to inform the development of a social-ecological systems framework (SESF) for the beekeeping industry in Western Australia.

\begin{tabular}{|c|c|c|c|c|}
\hline Stakeholder group & $\begin{array}{l}\text { Number of } \\
\text { participants }\end{array}$ & Method used & Duration & Outcome \\
\hline Full-time beekeeper & 14 & Semistructured interviews & $35-40$ minutes & Refinement of initial SESF variable list \\
\hline Part-time beekeeper & 15 & & & \\
\hline Government officials & 2 & Semistructured interviews & $\begin{array}{c}30-35 \\
\text { minutes }\end{array}$ & Refinement of initial SESF variable list \\
\hline $\begin{array}{l}\text { Research experts actively working } \\
\text { on vivid aspects of the bee } \\
\text { industry }\end{array}$ & 4 & Open-ended discussion & 2.5 hours & $\begin{array}{l}\text { Verification of the refined SESF } \\
\text { variable list relevant to the bee industry }\end{array}$ \\
\hline \multirow[t]{3}{*}{ Retired beekeepers } & 6 & Workshop & 5 hours & $\begin{array}{l}\text { Independent validation of the SESF } \\
\text { variable list relevant to the bee industry }\end{array}$ \\
\hline & & Mind mapping & & $\begin{array}{l}\text { Identification of key feedbacks within } \\
\text { the bee industry-SES }\end{array}$ \\
\hline & & & & $\begin{array}{l}\text { Identification of key pressures and their } \\
\text { potential effect on the bee industry-SES }\end{array}$ \\
\hline
\end{tabular}

presented below provide a narrative for the beekeeping industry in WA. As a first step in conceptualizing the beekeeping system as an SESF, a qualitative approach was ultimately adopted for this research.

Fig. 3. Retired beekeepers sharing their knowledge in the mind mapping session for validating social-ecological systems framework variables for the beekeeping industry. Green sticky notes were used to list environmental aspects, yellow for human aspects, and blue for key pressures.

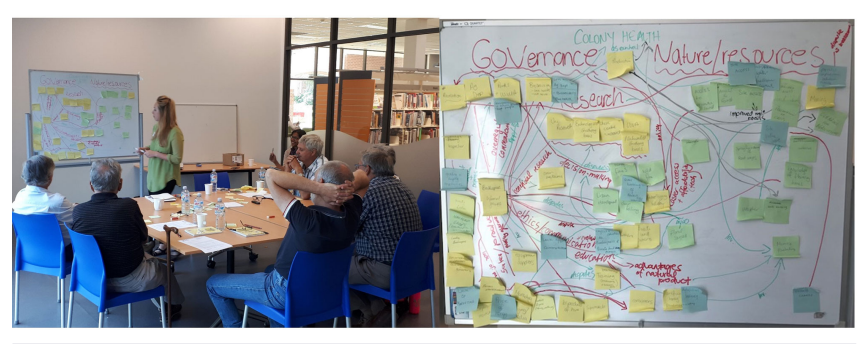

\section{RESULTS}

In total $168 \mathrm{SESF}$ variables for the WA beekeeping industry were identified, including 56 second tier, 72 third tier, and 32 fourth tier components (Fig. 4, Appendix 1). Further details on each of the SESF components are provided in the following sections.

\section{Core subsystems}

The core subsystems (Tier 1 variables) of the WA beekeeping industry included the Resource System (RS), Resource Units (RU), Actors (A), and Governance System (GS), as described following the variable list provided in McGinnis and Ostrom (2014; Fig. 2). Below we outline some of the first, second, third, and fourth tier variables to provide a narrative to support Figure 4 and the complete list in Appendix 1.

\section{Resource System ( RS)}

The landscape of bee resources (melliferous flora) forms the resource system for the beekeeping SES. Bee visitation of flora in various land uses such as forest (RS1a), agriculture (RS1b), or other plantations (RS1c) exhibit variable outcomes and access regulations. Setting apiaries within the forest boundary (RS2a) requires the maintenance of $3 \mathrm{~km}$ separation distance from other apiaries (RS2c). However, inapplicability of this mandate on private land across fence boundaries (RS2b) further highlights the position of human-constructed facilities (RS4) in accessing resources. Beekeepers have reported determining productivity of the forage landscape (RS5) according to spatial and seasonal variability of flowering events (RS7), location and association (RS9) of species, and information related to previous system disturbances (RS8). For instance, landscapes with high diversity forage species are reported to have longer flowering events, leading to healthy bees and higher yield with less travel. Additional RS variables at second and third tiers, as proposed by Vogt et al. (2015), include ecosystem histories (RS10) specific to natural disasters (RS10a) such as drought or bushfire (RS10b), and were included in the initial list and validated during the variable refinement process.

\section{Resource Unit ( $R U$ )}

Following the diagnostic questionnaire proposed by Hinkel et al. (2015), the Resource Unit (RU) is identified as the managed bee colony because it is involved in the generation of benefits from the SES and depends on the RS to survive and thrive. Mobility of beehives (RU1) is critical in migratory beekeeping where maintaining healthy and productive colonies (RU2) is the prime interest of the beekeepers (Pilati and Prestamburgo 2016, Pilati and Fontana 2018). Beehives are managed for honey production (RU5a) and for crop pollination (RU5b). Based on the total number of hives managed by a beekeeper, a load (approximately 100 hives can be transported by one flatbed truck) of hives (RU5ai) was added as a fourth tier variable. Load size and their spatial and temporal placement (RU7) depend on forage availability; for example, insufficient forage availability could result in splitting a load into smaller sizes (30-50 hives) but increases transport costs to accommodate their spatial-temporal arrangement. The value of beehives (RU4) was categorized as a market value (RU4a), environmental value (RU4b), and strategic 
Fig. 4. First and second tier social-ecological systems framework (SESF) variables that define the beekeeping industry in Western Australia. Third and fourth tier variables are provided in Appendix 1.

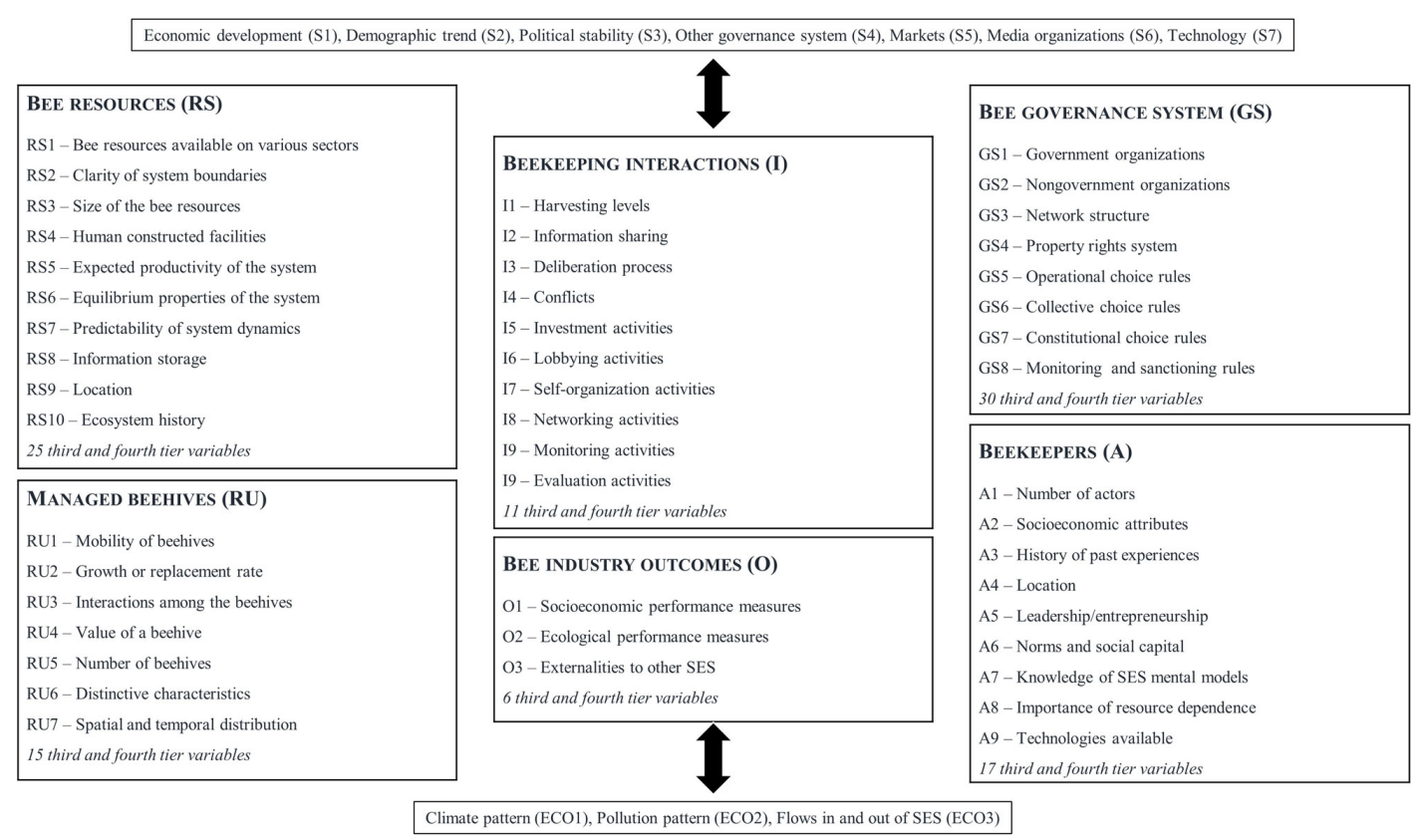

value (RU4c; Delgado-Serrano and Ramos 2015). The condition of the RS and RU are the most important factors contributing to social-ecological system sustainability (Frey 2016), and inter/ intraspecific interactions (RU3a/RU3b), including spatial proximity (RU3ai) of the resource units. Marking each hive (RU6a) with a registered brand is mandatory for all beekeepers in WA.

\section{Governance system (GS)}

Government organizations (GS1) that manage and monitor bee resources, e.g., DBCA, and bee stock, e.g., DPIRD, directly interact with beekeepers and operational activities at state-level organizations (GS1b) as well as the local government-level (GS1c). Contributions from research organizations (GS2b) were found to improve the beekeeping industry with $74 \%$ of beekeepers in Australia experiencing up to $25 \%$ increase in production by changing their management practices as a result of research (van Dijk et al. 2016). Based on sectoral research funding, fourth tier SESF variables were added for academic research (GS2bi), industry-funded research (GS2bii), and cooperative research centers (GS2biii). Social connections between beekeepers and land owners/managers (GS3a) and within beekeeper groups (GS3ai) are a key influencing factor regarding resource access and use, irrespective of the governing rules (GS5-7) because of an increasing reliance on private land. Conflict between beekeepers (I4a) can also be related to GS3a and GS3ai, as identified by several apiarists. In addition, constitutions related to beekeeping (GS7a), biosecurity (GS7b), access to resources (GS7c) including forest management (GS7cii), local government bylaws (GS7ciii), and food handling requirements (GS7civ) influence monitoring and sanctioning rules (GS8a-b) at a local level, and were added as fourth tier variables.
$\operatorname{Actors}(A)$

Migratory beekeepers are the key actors (A) in the bee-human system. Age and intergenerational involvement in beekeeping are key demographic attributes (Phillips 2014, Galbraith et al. 2017) that determine experience (A3) and local ecological knowledge (A7a). Based on diverse economic characteristics (A2b), four fourth tier SESF variables were identified: large-scale operators (> 499 hives; A2bi), small-scale operators (50-499 hives; A2bii), equipment manufacturers/suppliers (A2biii), honey packers, and queen bee breeders (A2biv). All large-scale operators were fulltime beekeepers (A8a) with total dependence on beekeeping for their livelihoods. Intergenerational beekeepers followed the knowledge of their parents and grandparents regarding the rich spatial-temporal history of resources, production, weather, and issues at their regular forage sites, and were also involved in sharing beekeeping knowledge by training new beekeepers (A5b). For other commercial and semicommercial beekeepers, a general transition of hobbyists from part-time (A8b) to full-time (A8a) beekeeping was observed. Various levels of technology (A9) were reported including mobile phone and internet to access information, and use of satellite imagery and other advanced sensor-based devices for hive resource monitoring; these were dependent upon the scale of operation, age of the beekeeper, and aspiration for future expansion.

Focal action situation: Key Interactions (I) and Outcomes (O) Information sharing (I2) concerning forage resources was reported as a main form of interaction between beekeepers. The state-level beekeeping organization (BICWA) is involved in deliberation (I3) and investment activities (I5) for the industry and has representatives from formal beekeeper groups (I2a) including hobbyists (WA apiarist society), semicommercial and commercial (WA beekeeper association, WA farmer federation), 
and the committee of producers (Agriculture Produce Commission). Additionally, there are known informal beekeeper groups (I2b) with various levels of interaction.

Several conflicts were included as SESF variables because they were identified by the majority of participants as affecting governance of the bee-human system. Conflict between beekeepers (I4a) can arise where one beekeeper is seen to harvest resources from another beekeeper's patch; generally by placing hives on the edge of private land next to forest. Such situations may unfold due to noncompliance of the $3 \mathrm{~km}$ apiary separation regulation on private land ( $\mathrm{RS} 2 \mathrm{c})$. Close colony proximity can also inadvertently increase biosecurity risk through compromised hive health (e.g., disease transmission), potentially leading to a loss of hives. In addition, loss of bees due to use of fungicide by a farmer hiring beehives for pollination services was also identified as a point of contention (I4b). Conflict also exists between regulatory authorities, e.g., DBCA, and beekeepers regarding loss of forage resources due to land management practices, such as prescribed burning (I4c).

Harvests vary by beekeeper (I1a) and depend on the number of hive holdings, knowledge, and access to forage resources and other socioeconomic attributes. Different forage locations (I1b) lead to variability in yield (quantity) and quality as a result of vegetation mix and health. Resource monitoring activities (I9a) carried out by beekeepers are based on monitoring rules (GS8) developed by government organizations (GS1) and influence hive migration patterns and expected productivity of forage sites (RS5). However, decision making for migration of beehives also depends on the growth and replacement rate (RU2) of the hives, hence, beehive monitoring activities (I9b) was added as a variable under monitoring activities.

When beekeepers do not receive payment for pollination, it is considered an externality (O3ai) of the system flowing to agriculture and forest systems alike (Siebert 1980, IPBES 2016). Combining beekeeping with other industries, e.g., api-tourism in Slovenia, can have multiplier effects on regional economies and support improved management (Gemeda 2014, Arih and Korošec 2015). Packaging industries (O3aii) was added as a positive externality. Resource competition with other species (O3bi) and potential for disease transmission (O3bii) through migratory practices was identified as a negative externality $(\mathrm{O} 3 \mathrm{~b})$. Interaction between bees and beekeepers (I9b) is integral to beekeeping activities and affects overall beehive migration patterns. For example, beekeepers managing a large number of hives tend to visit a number of sites across the state, and move greater distances from their home location, when compared to a small-scale, part-time beekeepers.

\section{Sustainability pressures}

Key pressures that affect the sustainability of the WA bee-human system were identified. Responses to interview questions related to issues and pressures (see Appendix 2) with beekeepers and government representatives were analyzed to calculate how many participants mentioned each pressure (see Table 2). All listed pressures were independently validated by the retired beekeepers group except for "backward in technology usage." The three top pressures mentioned by stakeholders were (i) availability, access, and utilization of apiary sites, (ii) burning of forage resources, and (iii) climate change. These pressures were mentioned by the majority of interviewees and focus group participants and received consensus in all stakeholder engagements (see Table 2).

Table 2. Pressures on the Western Australia bee-human system according to the number of people in each stakeholder group who mentioned each pressure. Retired beekeepers independently validated pressures during a collective workshop, hence their responses are noted as a binary yes-no.

\begin{tabular}{|c|c|c|c|}
\hline Pressure & $\begin{array}{l}\text { Beekeepers } \\
(n=29)\end{array}$ & $\begin{array}{l}\text { Government } \\
\text { representatives } \\
\quad(n=2)\end{array}$ & $\begin{array}{c}\text { Retired } \\
\text { beekeepers } \\
(n=6)\end{array}$ \\
\hline Availability/access to forage sites & 18 & 1 & $\sqrt{ }$ \\
\hline Burning of forage resources & 17 & 1 & $\sqrt{ }$ \\
\hline Climate change & 12 & 1 & $\sqrt{ }$ \\
\hline $\begin{array}{l}\text { Lack of rainfall and/or declining } \\
\text { water table }\end{array}$ & 10 & 0 & $\sqrt{ }$ \\
\hline Land use / land cover change & 9 & 0 & $\sqrt{ }$ \\
\hline Biosecurity & 8 & 2 & $\sqrt{ }$ \\
\hline Logging & 4 & 0 & $\sqrt{ }$ \\
\hline Underutilization of sites & 3 & 1 & $\sqrt{ }$ \\
\hline Variability in flowering & 3 & 1 & $\sqrt{ }$ \\
\hline Government (in)action & 3 & 0 & $\sqrt{ }$ \\
\hline Hive theft and vandalism & 2 & 0 & $\sqrt{ }$ \\
\hline $\begin{array}{l}\text { Spraying of fungicides and } \\
\text { insecticides }\end{array}$ & 2 & 0 & $\sqrt{ }$ \\
\hline Lack of communication & 2 & 1 & $\sqrt{ }$ \\
\hline Cheap honey & 1 & 0 & $\sqrt{ }$ \\
\hline Backward in technology usage & 1 & 0 & \\
\hline Lack of authority to monitor sites & 1 & 2 & $\sqrt{ }$ \\
\hline
\end{tabular}

\section{DISCUSSION}

Global bee decline and its likely consequences for human wellbeing are increasingly being recognized (Gill et al. 2016, Potts et al. 2016, Klein et al. 2018). A multitude of natural and anthropogenic factors have been attributed to this decline, including depletion of forage resources (Goulson et al. 2015, Durant 2019). Although forage scarcity results from both natural (e.g., phenological mismatch) and anthropogenic (e.g., land use change) factors, effects of forage scarcity is detrimental to all bee populations and could potentially contribute to resource competition between wild and managed bees. A clearer understanding of bee-human systems can provide a potential pathway to better manage ecosystem services delivered by managed bees (Gill et al. 2016, Potts et al. 2016, Matias et al. 2017, Klein et al. 2018, Patel et al. 2020).

We have described the first application of the SESF to the beekeeping sector, enabling us to understand the structural interconnectivities within the beekeeping SES and the challenges that threaten the sustainability of the system. Decision makers can use our SESF to direct management operations for minimizing trade-offs and maximizing synergies for system components to work toward optimized system functionality. We provide insights to illustrate potential use of our SESF by showcasing three examples that relate to the top three system pressures identified during the data collection process. The SESF can provide a structured response mechanism for enhancing environmental management of the beekeeping industry and guide sustainable decision making for managing system pressures, including those that are under immediate control of state policy 
Fig. 5. Priority pressures of (i) availability, access and utilization of forage sties, (ii) a changing climate, and (iii) burning of forage resources. Each diagram indicates the impact of the pressure on various components and example feedback pathways within the beekeeping social-ecological system (SES) in Western Australia (refer to Appendix 1 for variable coding). The diagrams are formatted to match the SES framework core components illustrated in Figure 2.

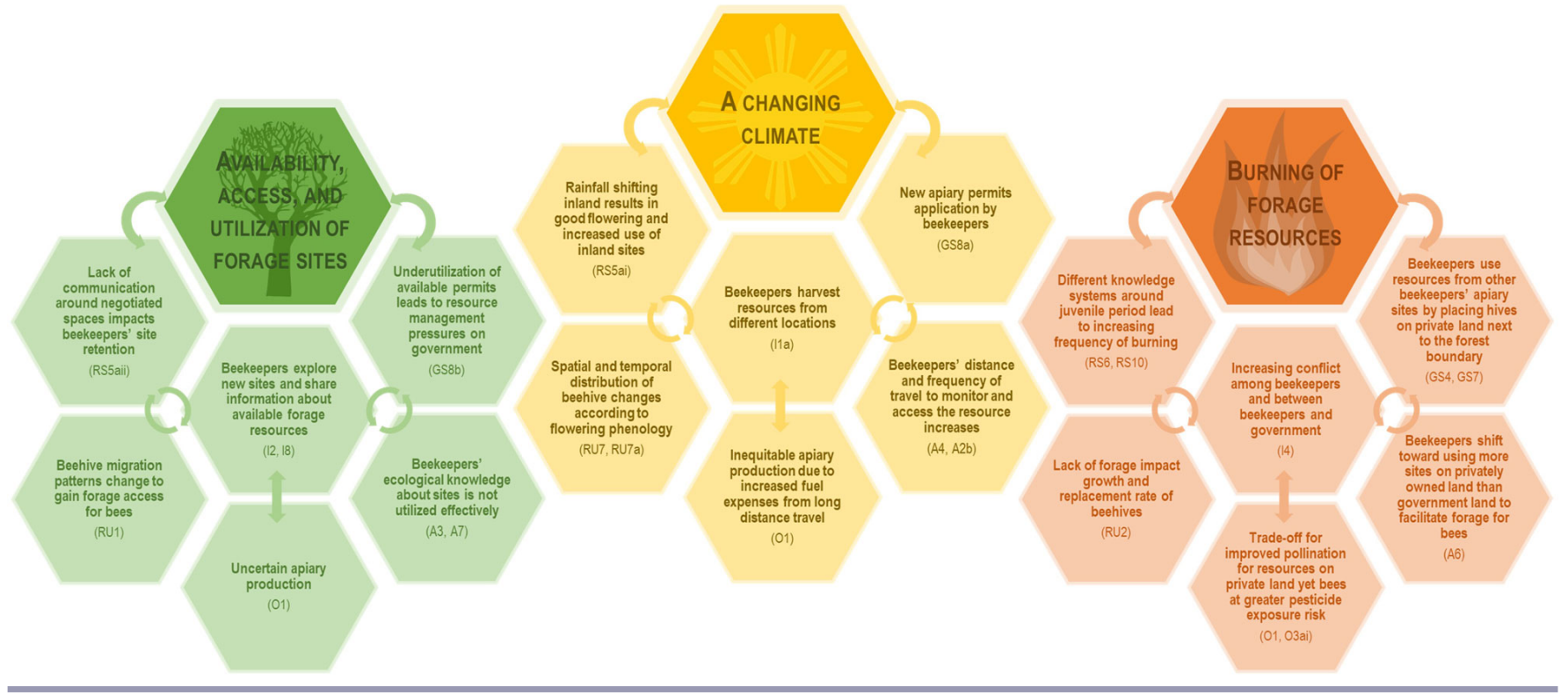

makers, e.g., forage access or burning of resources, and also those that require long-term systematic change, e.g., climate change or rainfall shifts.

\section{Addressing priority bee-human system pressures}

Changes affecting bee-human systems are generally socio-cultural, environmental, economic, and governance-oriented in nature (Matias et al. 2017). Sustainability of the beekeeping industry depends on continuous access of quality forage sites (Pilati and Prestamburgo 2016). Challenges such as decreasing resource access and biosecurity risks have been previously documented for the Australian beekeeping industry (Phillips 2014), and reinforced through our data collection. To address key pressures using the SESF, interconnectivities where synergies and trade-offs occur are illustrated in Figure 5. This provides insights into the elements and feedback processes contributing to the top three pressures (discussed in the following section) identified for the WA beekeeping industry.

\section{Availability, access, and utilization of apiary sites}

In migratory beekeeping, sustainability varies according to the sequence of apiary sites accessed by a beekeeper (Pilati and Prestamburgo 2016). Beekeepers' access to forage sites depends on a range of factors including biophysical conditions (e.g., blocked physical access due to vegetation growth), legislation (e.g., burning regimes), negotiations (e.g., with land owner or existing lease holder), changing land management practices (e.g., approval of new walking trails; RS5ai), and change in individual practice (e.g., upgrading truck size limits access to sites only accessible with smaller vehicles). The importance of forage locations with high species diversity (Coh-Martínez et al. 2019) and increasing variability in flowering events cause full-time beekeepers to maintain a number of underused sites as backup (Fig. 5). In addition, technological progress in management initiatives also contributes to variability in SESs; for example, in WA, an online portal designed to ease the apiary permit process has been attributed to increasing vandalism and hive-theft after apiary site locations were made available online.

A national level policy change can also add to SES variability. For example, revising the regulation of holding permits per number of hives, under the National Competition Legislation (CALM 1997), has resulted in conflict among beekeepers because of withholding apiary permits for earning rent rather than providing forage. This underuse of resources (Mauerhofer et al. 2018, Miyanaga and Shimada 2018) requires beekeepers to find new sites, and change hive migration patterns (RU1), leading to uncertain apiary production $(\mathrm{O} 1)$. Such situations can result in increased resource management pressure on the government (GS8b). In addition, conservation initiatives, aimed at limiting the interactions of managed bees with natural ecosystems, can also affect a beekeeper's access to resources. The issue of availability and access to resources largely contributes to SES sustainability (Frey 2016) and requires an understanding of the nonlinear nature of SES interactions in order to avoid siloed decisions. Key variables and interactions identified in this research provide the basis to guide integrated decisions toward sustainable resource access for bee-human systems.

\section{A changing climate}

Beekeeping activities are heavily influenced by climatic conditions, including rainfall and temperature. A positive correlation between rainfall and winter survival of bee colonies (Switanek et al. 2017) and honey harvest (Delgado et al. 2012) has been noted in the literature. Rainfall patterns are regularly observed by beekeepers for predicting flowering events. The 
juvenile period of bee forage species varies geographically and is also connected with variations in rainfall (Burrows et al. 2008, Bradshaw et al. 2018, Shedley et al. 2018). Terms such as "patchy flowering," "uneven production," and "consistently random flowering" were used by beekeepers to describe climate effects on the resource system. In addition, lack of nectar, thinning of nectar, and bitter nectar were reported and associated with climate change.

A relationship between rainfall patterns and flowering events (and nectar production) is evident with increasing use of inland forage sites (toward Coolgardie: Fig. 1) to access good flowering events, i.e., a hive filled with honey within two weeks, resulting from increasingly variable precipitation. Rainfall shifts toward inland areas are supporting beekeepers with additional forage sites (RS5ai) but may lead to inequitable production $(\mathrm{O} 1)$ because of fuel intensive, long-distance travel involved with accessing more remote locations. In addition, our SESF analysis has revealed impacts on other parts of the SES. For example, unpredictable flowering also escalates beekeepers' travel expenditure because of additional site visits to confirm resource availability prior to utilization (A4, A2b; Fig. 5).

\section{Burning of forage resources}

Beekeepers understand fire in great detail, including frequency, intensity, and extent of disturbance. Forage species in the Mediterranean-type climates have naturally adapted to fires, however a species' response during the juvenile period - capacity of species to produce flowers and nectar-varies and depends on the frequency and intensity of burning (Bradshaw et al. 2018, Shedley et al. 2018). For instance, as cited in Bradshaw et al. (2018), Banksia sessilis takes 12-15 years postfire to reach maximum honey production, and frequent burns can result in loss of the species. In the SWAFR, almost 180,000 ha is burnt annually by DBCA to manage fuel load and avoid catastrophic fire events (Bradshaw et al. 2018). An association between burning and underutilization of sites is evident from beekeepers' statements such as "All our products go to smoke," "Parrot bush [Banksia sessilis] is completely lost to frequent burning at the coast," and "We use more private sites now government sites are not reliable - it's frequently burnt" (GS4,GS7).

Reducing harvesting levels or a complete loss of crop (nectarbearing flowers) due to frequency, intensity, and timing (during budding season) of prescribed burns was noted as the main cause of conflict between beekeepers and government organizations (I4; Fig. 5). We identified contradictory views regarding recovery of species after burning between government officials and beekeepers (RS6, RS10). This represents a critical gap between two knowledge systems and a challenge of integrating beekeepers' practical knowledge obtained through regular monitoring of flora with land management practices.

\section{Understanding structural interconnectivities}

Aligning management decisions to the complex, spatially explicit dynamics associated with human and ecological systems is vital in addressing sustainability issues and effective spatial planning in a SES (Leslie et al. 2015, Ovitz and Johnson 2019). The multiscale, multidirectional applicability of our SESF provides opportunity to understand complex interconnectivities leading to these SES dynamics within the beekeeing industry. Understanding the structural interconnectivities of the beekeeping system through SESF mapping has revealed impacts on other parts of the SES that may not have been initially obvious. For example, a preference by beekeepers to access resources closer to their home location, i.e., close to urban and peri-urban areas to save the time and costs involved in hive-transportation, can lead to increased intensity of resource use and high competitiveness within close proximity to urban, peri-urban systems. Research findings indicate that migration decisions by beekeepers reflect self-organization within the beekeeping SES, with part-time beekeepers preferring to migrate hives within a couple of hundred kilometers from their home location, whereas full-time (mostly family) beekeepers are willing to migrate hives longer distances to access forage resources.

The importance of integrating local ecological knowledge with local management practices in SES is also highlighted in our research (Maderson and Wynne-Jones 2016, Uchiyama et al. 2017, Colding and Barthel 2019, Hill et al. 2019) through the identification of third and fourth tier variables aided by multigenerational beekeepers. Through considering the spatially explicit nature of social-ecological interactions, collective action involving local actors and the government may result in more effective spatial planning for the industry (Nagendra and Ostrom 2014, Leslie et al. 2015, Dressel et al. 2018, Partelow et al. 2018a). For instance, beekeepers' local knowledge can be used to adjust burning regimes and schedules to avoid burning flora during budding or nectar flow.

\section{CONCLUSION}

In this paper we have presented the first application of Ostrom's SESF to understand structural interconnectivities within the beekeeping industry. We combined various qualitative research methods to identify important social and ecological components of the bee-human system and their interconnectivities. We also identified and discussed key social-ecological pressures to the beekeeping industry, highlighting the need for integrated decision making and incorporation of local ecological knowledge in management decisions. As such, our SESF assessment can be used to facilitate multidirectional communication and knowledge exchange between beekeeping industry actors to address stakeholder needs, particularly for the improved management of common pooled resources. Additionally, the framework can be used to inform integrated policy design in order to sustain apiary production while safeguarding bee-diversity and associated ecosystem services. Although certain lower tier variables, e.g., apiary permits (GS8ai), proximity of resource units (RU3ai), and load size (RU5ai), are unavoidably specific to the WA system, the diagnosis presented here can guide sustainable management decision making associated with other bee-human systems including wild bee conservation and nonmigratory beekeeping, as well as migratory beekeeping in alternative geographical locations. For example, conflicts arising from competition over Manuka resources in New Zealand (Lloyd 2017) could be managed using our SESF given the transferability of first and second tier variables across systems. Our recommendation is to build upon this foundational research to initiate a framework application to quantitatively investigate the outcomes of system interconnectivities (e.g., Leslie et al. 2015, Dressel et al. 2018, Pacilly et al. 2019) within the bee-human system. Such an approach would enable complex social-ecological systems modeling to test the implications of behavioral decision making, 
such as exploring how factors that govern landscape mobility affect beehive migration and impact system sustainability.

${ }^{[1]}$ In this paper, we use the word "bee" as shorthand to refer to the European honeybee, Apis mellifera. We recognize that there are approximately 20,000 described species of bee, of which 50 are managed species, the honeybee being one of them.

${ }^{[2]}$ Acknowledging that the European honeybee is a non-native species in Western Australia, in this paper we consider only managed honeybee colonies and do not consider feral honeybees. Feral bees have a suite of associated conservation issues including taking over suitable nesting hollows for native birds, mammals, and reptiles (Gibbons and Lindenmeyer 2002, Johnstone et al. 2013).

${ }^{[3]}$ In this paper we define the beekeeping industry to represent commercial (apiarists managing more than 500 hives) and semicommercial beekeepers (apiarists managing between 50 and 500 hives) in WA.

${ }^{[4]}$ Five members were selected to form the advisory group based on an individual's reputation within the beekeeping industry and ensuring a diverse representation of stakeholder groups, which included government agencies, private businesses, research institutions, and beekeeping organizations.

Responses to this article can be read online at: http://www.ecologyandsociety.org/issues/responses. php/11639

\section{Acknowledgments:}

This research was undertaken with funding support from the Cooperative Research Centre for Honey Bee Products and the Faculty of Science, University of Western Australia. We thank Bee Industry Council of Western Australia (BICWA) for helping us to showcase our research and recruit participants from the beekeepers across WA. We further acknowledge all our participants including beekeepers, government representatives, and advisory group members for contributing their time and knowledge to this research. We also appreciate Manita Narongsirikul for her support during the data collection process. We are thankful to three anonymous reviewers for providing valuable feedback to improve this paper.

\section{Data Availability Statement:}

The aggregated data that support the findings of this study are included within the publication as an appendix. The raw data are not publicly available because of ethical restrictions around maintaining anonymity of research participants.

\section{LITERATURE CITED}

Acosta, C., M. Ortega, T. Bunsen, B. Koirala, and A. Ghorbani. 2018. Facilitating energy transition through energy commons: an application of socio-ecological systems framework for integrated community energy systems. Sustainability 10(2):366. https://doi. org/10.3390/su10020366
Aizen, M. A., S. Aguiar, J. C. Biesmeijer, L. A. Garibaldi, D. W. Inouye, C. Jung, D. J. Martins, R. Medel, C. L. Morales, H. Ngo, A. Pauw, R. J. Paxton, A. Sáez, and C. L. Seymour. 2019. Global agricultural productivity is threatened by increasing pollinator dependence without a parallel increase in crop diversification. Global Change Biology 25(10):3516-3527. https://doi.org/10.1111/ gcb. 14736

Aizen, M. A., and L. D. Harder. 2009. The global stock of domesticated honey bees is growing slower than agricultural demand for pollination. Current Biology 19:915-918. https://doi. org/10.1016/j.cub.2009.03.071

Andrich, M. A., and J. Imberger. 2013. The effect of land clearing on rainfall and fresh water resources in Western Australia: a multifunctional sustainability analysis. International Journal of Sustainable Development and World Ecology 20:549-563. https:// doi.org/10.1080/13504509.2013.850752

Arih, I. K., and T. A. Korošec. 2015. Api-tourism: transforming Slovenia's apicultural traditions into a unique travel experience. WIT Transactions on Ecology and the Environment 193:963-974. https://doi.org/10.2495/SDP150811

Arundel, J., S. Winter, G. Gui, and M. Keatley. 2016. A web-based application for beekeepers to visualise patterns of growth in floral resources using MODIS data. Environmental Modelling \& Software 83:116-125. https://doi.org/10.1016/j.envsoft.2016.05.010

Basurto, X., S. Gelcich, and E. Ostrom. 2013. The socialecological system framework as a knowledge classificatory system for benthic small-scale fisheries. Global Environmental Change 23:1366-1380. https://doi.org/10.1016/j.gloenvcha.2013.08.001

Batley, M., and K. Hogendoorn. 2009. Diversity and conservation status of native Australian bees. Apidologie 40(3):347-354. https:// doi.org/10.1051/apido/2009018

Benecke, F. S. 2007. Commercial beekeeping in Australia. Rural Industries Research and Development Corporation, Canberra, Australia. [online] URL: https://www.agrifutures.com.au/wpcontent/uploads/publications/07-059.pdf

Binder, C. R., J. Hinkel, P. W. G. Bots, and C. Pahl-Wostl. 2013. Comparison of frameworks for analyzing social-ecological systems. Ecology and Society 18(4):26. https://doi.org/10.5751/ ES-05551-180426

Bradbear, N. 2009. Bees and their role in forest livelihoods: a guide to the services provided by bees and the sustainable harvesting, processing and marketing of their products. Food and Agriculture Organization of the United Nations, Rome, Italy. [online] URL: http://www.fao.org/3/a-i0842e.pdf

Bradshaw, S. D., K. W. Dixon, H. Lambers, A. T. Cross, J. Bailey, and S. D. Hopper. 2018. Understanding the long-term impact of prescribed burning in Mediterranean-climate biodiversity hotspots, with a focus on south-western Australia. International Journal of Wildland Fire 27:643-657. https://doi.org/10.1071/ WF18067

Brouwers, N. C., J. Mercer, T. Lyons, P. Poot, E. Veneklaas, and G. Hardy. 2013. Climate and landscape drivers of tree decline in a Mediterranean ecoregion. Ecology and Evolution 3:67-79. https://doi.org/10.1002/ece3.437 
Burrows, N., G. Wardell-Johnson, and B. Ward. 2008. Post-fire juvenile period of plants in south-west Australia forests and implications for fire management. Journal of the Royal Society of Western Australia 91:163.

Carroll, T., and J. Kinsella. 2013. Livelihood improvement and smallholder beekeeping in Kenya: the unrealised potential. Development in Practice 23:332-345. https://doi.org/10.1080/096$\underline{14524.2013 .781123}$

Chapman, N. C., J. Lim, and B. P. Oldroyd. 2008. Population genetics of commercial and feral honey bees in Western Australia. Journal of Economic Entomology 101:272-277. https://doi. org/10.1093/jee/101.2.272

Coh-Martínez, M. E., W. Cetzal-Ix, J. F. Martínez-Puc, S. K. Basu, E. Noguera-Savelli, and M. J. Cuevas. 2019. Perceptions of the local beekeepers on the diversity and flowering phenology of the melliferous flora in the community of Xmabén, Hopelchén, Campeche, Mexico. Journal of Ethnobiology and Ethnomedicine 15:16. https://doi.org/10.1186/s13002-019-0296-1

Colding, J., and S. Barthel. 2019. Exploring the social-ecological systems discourse 20 years later. Ecology and Society 24(1):2. https://doi.org/10.5751/es-10598-240102

Conservation and Land Management (CALM). 1997. Position paper on the trading and administration of apiary sites on crown land and land managed by the Department of Conservation and Land Management (CALM). CALM, Como, Western Australia, Australia.

Crooks, S. 2008. Australian honeybeekeeping industry survey 2006-07. Rural Industries Research and Development Corporation, Canberra, Australia. [online] URL: https://www. agrifutures.com.au/wp-content/uploads/publications/08-170.pdf

Dangles, O., and J. Casas. 2019. Ecosystem services provided by insects for achieving sustainable development goals. Ecosystem Services 35:109-115. https://doi.org/10.1016/j.ecoser.2018.12.002

Dawes, W., R. Ali, S. Varma, I. Emelyanova, G. Hodgson, and D. McFarlane. 2012. Modelling the effects of climate and land cover change on groundwater recharge in south-west Western Australia. Hydrology and Earth System Sciences 16:2709-2722. https://doi.org/10.5194/hess-16-2709-2012

Delgado, D. L., M. E. Pérez, A. Galindo-Cardona, T. Giray, and C. Restrepo. 2012. Forecasting the influence of climate change on agroecosystem services: potential impacts on honey yields in a small-island developing state. Psyche: A Journal of Entomology 2012:951215. https://doi.org/10.1155/2012/951215

Delgado-Serrano, M. del M., and P. Ramos. 2015. Making Ostrom's framework applicable to characterise social ecological systems at the local level. International Journal of the Commons 9(2):808-830. https://doi.org/10.18352/ijc.567

Dressel, S., G. Ericsson, and C. Sandström. 2018. Mapping socialecological systems to understand the challenges underlying wildlife management. Environmental Science \& Policy 84:105-112. https://doi.org/10.1016/j.envsci.2018.03.007

Durant, J. L. 2019. Where have all the flowers gone? Honey bee declines and exclusions from floral resources. Journal of Rural Studies 65:161-171. https://doi.org/10.1016/j.jrurstud.2018.10.007
Elsawah, S., J. H. A. Guillaume, T. Filatova, J. Rook, A. J. Jakeman. 2015. A methodology for eliciting, representing, and analysing stakeholder knowledge for decision making on complex socio-ecological systems: from cognitive maps to agent-based models. Journal of Environmental Management 151:500-516. https://doi.org/10.1016/j.jenvman.2014.11.028

Evans, E., M. Smart, D. Cariveau, and M. Spivak. 2018. Wild, native bees and managed honey bees benefit from similar agricultural land uses. Agriculture, Ecosystems \& Environment 268:162-170. https://doi.org/10.1016/j.agee.2018.09.014

Frey, U. J. 2016. A synthesis of key factors for sustainability in social-ecological systems. Sustainability Science 12:507-519. https://doi.org/10.1007/s11625-016-0395-Z

Frey, U. J., and M. Cox. 2015. Building a diagnostic ontology of social-ecological systems. International Journal of the Commons 9:595-618. https://doi.org/10.18352/ijc.505

Galbraith, S. M., T. E. Hall, H. S. Tavárez, C. M. Kooistra, J. C. Ordoñez, and N. A. Bosque-Pérez. 2017. Local ecological knowledge reveals effects of policy-driven land use and cover change on beekeepers in Costa Rica. Land Use Policy 69:112-122. https://doi.org/10.1016/j.landusepol.2017.08.032

Gemeda, T. K. 2014. Integrating improved beekeeping as economic incentive to community watershed management: the case of Sasiga and Sagure districts in Oromiya region, Ethiopia. Agriculture, Forestry and Fisheries 3:52-57. https://doi. org/10.11648/j.aff.20140301.19

Geslin, B., B. Gauzens, M. Baude, I. Dajoz, C. Fontaine, M. Henry, L. Ropars, O. Rollin, E. Thébault, and N. J. Vereecken. 2017. Massively introduced managed species and their consequences for plant-pollinator interactions. Advances in Ecological Research 57:147-199. https://doi.org/10.1016/bs. aecr.2016.10.007

Gibbons, P., and D. Lindenmayer. 2002. Tree hollows and wildlife conservation in Australia. CSIRO, Collingwood, Australia. https://doi.org/10.1071/9780643090033

Gibbs, D. M. H., and I. F. Muirhead. 1998. The economic value and environmental impact of the Australian beekeeping industry: a report prepared for the Australian beekeeping industry. Australian Honeybee Industry Council, Maroubra, Australia. [online] URL: https://www.honeybee.com.au/Library/gibsmuir.html

Gill, R. J., K. C. R. Baldock, M. J. F. Brown, J. E. Cresswell, L. V. Dicks, M. T. Fountain, M. P. D. Garratt, L. A. Gough, M. S. Heard, J. M. Holland, J. Ollerton, G. N. Stone, C. Q. Tang, A. J. Vanbergen, A. P. Vogler, G. Woodward, A. N. Arce, N. D. Boatman, R. Brand-Hardy, T. D. Breeze, M. Green, C. M. Hartfield, R. S. O'Connor, J. L. Osborne, J. Phillips, P. B. Sutton, and S. G. Potts. 2016. Protecting an ecosystem service: approaches to understanding and mitigating threats to wild insect pollinators. Pages 135-206 in G. Woodward and D. A. Bohan, editors. Advances in ecological research. Academic, London, UK. https:// doi.org/10.1016/bs.aecr.2015.10.007

Goodman, R. 2014. Australian beekeeping guide. Rural Industries Research and Development Corporation, Canberra, Australia. [online] URL: https://www.agrifutures.com.au/wp-content/uploads/ publications/14-098.pdf 
Gordon, R., N. Bresolin-Schott, and I. J. East. 2014. Nomadic beekeeper movements create the potential for widespread disease in the honeybee industry. Australian Veterinary Journal 92 (8):283-290. https://doi.org/10.1111/avj.12198

Goulson, D., E. Nicholls, C. Botías, and E. L. Rotheray. 2015. Bee declines driven by combined stress from parasites, pesticides, and lack of flowers. Science 347(6229):1255957. https://doi. org/10.1126/science. 1255957

Hill, R., G. Nates-Parra, J. J. G. Quezada-Euán, D. Buchori, G. Lebuhn, M. M. Maués, P. L. Pert, P. K. Kwapong, S. Saeed, S. J. Breslow, M. Carneiro Da Cunha, L. V. Dicks, L. Galetto, M. Gikungu, B. G. Howlett, V. L. Imperatriz-Fonseca, P. O'B. Lyver, B. Martín-López, E. Oteros-Rozas, S. G. Potts, and M. Roué. 2019. Biocultural approaches to pollinator conservation. Nature Sustainability 2:214-222. https://doi.org/10.1038/s41893-019-0244$\underline{\mathrm{Z}}$

Hinkel, J., M. E. Cox, M. Schlüter, C. R. Binder, and T. Falk. 2015. A diagnostic procedure for applying the social-ecological systems framework in diverse cases. Ecology and Society 20(1):32. https://doi.org/10.5751/ES-07023-200132

House of Representatives Standing Committee on Primary Industries and Resources. 2008. More than honey: the future of the Australian honey bee and pollination industries: report of the inquiry into the future development of the Australian honey bee industry. Parliamentary Paper no. 294. Parliament of Australia, Canberra, Australia. [online] URL: https://www.aph.gov.au/ parliamentary business/committees/house of representatives committees? url=/pir/honeybee/report.htm

Hughes, L. 2011. Climate change and Australia: key vulnerable regions. Regional Environmental Change 11:189-195. https://doi. org/10.1007/s10113-010-0158-9

Intergovernmental Science-Policy Platform on Biodiversity and Ecosystem Services (IPBES). 2016. The assessment report on pollinators, pollination and food production. S. G. Potts, V. L. Imperatriz-Fonseca, and H. T. Ngo, editors. IPBES, Bonn, Germany.

Johnson, T. R., K. Beard, D. C. Brady, C. J. Byron, C. Cleaver, K. Duffy, N. Keeney, M. Kimble, M. Miller, S. Moeykens, M. Teisl, G. P. Van Walsum, and J. Yuan. 2019. A social-ecological system framework for marine aquaculture research. Sustainability 11(9):2522. https://doi.org/10.3390/su11092522

Johnstone, R. E., T. Kirby, and K. Sarti. 2013. The breeding biology of the forest Red-tailed Black Cockatoo Calyptorhynchus banksii naso Gould in south-western Australia. I. Characteristics of nest trees and nest hollows. Pacific Conservation Biology 19 (2):121-142. https://doi.org/10.1071/pc130121

Kleijn, D., K. Biesmeijer, Y. L. Dupont, A. Nielsen, S. G. Potts, and J. Settele. 2018. Bee conservation: inclusive solutions. Science 360(6387):389-390. https://doi.org/10.1126/science.aat2054

Klein, A.-M., V. Boreux, F. Fornoff, A.-C. Mupepele, and G. Pufal. 2018. Relevance of wild and managed bees for human wellbeing. Current Opinion in Insect Science 26:82-88. https://doi. org/10.1016/j.cois.2018.02.011

Knapp, C. N., M. Fernandez-Gimenez, E. Kachergis, and A. Rudeen. 2011. Using participatory workshops to integrate state- and-transition models created with local knowledge and ecological data. Rangeland Ecology \& Management 64:158-170. https://doi.org/10.2111/REM-D-10-00047.1

Lehébel-Péron, A., P. Sidawy, E. Dounias, and B. Schatz. 2016. Attuning local and scientific knowledge in the context of global change: the case of heather honey production in southern France. Journal of Rural Studies 44:132-142. https://doi.org/10.1016/j. jrurstud.2016.01.005

Leslie, H. M., X. Basurto, M. Nenadovic, L. Sievanen, K. C. Cavanaugh, J. J. Cota-Nieto, B. E. Erisman, E. Finkbeiner, G. Hinojosa-Arango, M. Moreno-Báez, S. Nagavarapu, S. M. W. Reddy, A. Sánchez-Rodríguez, K. Siegel, J. J. UlibarriaValenzuela, A. H. Weaver, and O. Aburto-Oropeza. 2015. Operationalizing the social-ecological systems framework to assess sustainability. Proceedings of the National Academy of Sciences USA 112:5979-5984. https://doi.org/10.1073/pnas.1414640112

Lloyd, P.2017. Competition in the Manuka honey industry in New Zealand. Department of Economics, Working Papers Series 2033. The University of Melbourne, Australia. [online] URL: https:// fbe.unimelb.edu.au/ data/assets/pdf file/0006/2484366/2033 PeterLloyd Manuka-Honey.pdf

Maderson, S., and S. Wynne-Jones. 2016. Beekeepers'knowledges and participation in pollinator conservation policy. Journal of Rural Studies 45:88-98. https://doi.org/10.1016/j.jrurstud.2016.02.015

Malkamäki, A., A. Toppinen, and M. Kanninen. 2016. Impacts of land use and land use changes on the resilience of beekeeping in Uruguay. Forest Policy and Economics 70:113-123. https://doi. org/10.1016/j.forpol.2016.06.002

Mallinger, R. E., H. R. Gaines-Day, and C. Gratton. 2017. Do managed bees have negative effects on wild bees? A systematic review of the literature. PLoS ONE 12(12):e0189268. https://doi. org/10.1371/journal.pone.0189268

Marshall, G. R. 2015. A social-ecological systems framework for food systems research: accommodating transformation systems and their products. International Journal of the Commons 9:881-908. https://doi.org/10.18352/ijc.587

Mastrantonis, S., M. D. Craig, M. Renton, T. Kirkby, and R. J. Hobbs. 2019. Climate change indirectly reduces breeding frequency of a mobile species through changes in food availability. Ecosphere 10:e2656. https://doi.org/10.1002/ecs2.2656

Matias, D. M. S., J. Leventon, A.-L. Rau, C. Borgemeister, and H. Von Wehrden. 2017. A review of ecosystem service benefits from wild bees across social contexts. Ambio 46:456-467. https:// doi.org/10.1007/s13280-016-0844-Z

Mauerhofer, V., T. Ichinose, B. D. Blackwell, M. R. Willig, C. G. Flint, M. S. Krause, and M. Penker. 2018. Underuse of socialecological systems: a research agenda for addressing challenges to biocultural diversity. Land Use Policy 72:57-64. https://doi. org/10.1016/j.landusepol.2017.12.003

McGinnis, M. D., and E. Ostrom. 2014. Social-ecological system framework: initial changes and continuing challenges. Ecology and Society 19(2):30. https://doi.org/10.5751/ES-06387-190230

Minja, G. S., and T. J. Nkumilwa. 2016. The role of beekeeping on forest conservation and poverty alleviation in Moshi Rural 
District, Tanzania. European Scientific Journal 12:366. https:// doi.org/10.19044/esj.2016.v12n23p366

Miyanaga, K., and D. Shimada. 2018. 'The tragedy of the commons' by underuse: toward a conceptual framework based on ecosystem services and satoyama perspective. International Journal of the Commons 12:332-351. https://doi.org/10.18352/ ijc. 817

Nagendra, H., and E. Ostrom. 2014. Applying the socialecological system framework to the diagnosis of urban lake commons in Bangalore, India. Ecology and Society 19(2):67. https://doi.org/10.5751/ES-06582-190267

Ostrom, E. 2009. A general framework for analyzing sustainability of social-ecological systems. Science 325:419-422. https://doi.org/10.1126/science.1172133

Ostrom, E., and M. Cox. 2010. Moving beyond panaceas: a multitiered diagnostic approach for social-ecological analysis. Environmental Conservation 37:451-463. https://doi.org/10.1017/ $\underline{\mathrm{S} 0376892910000834}$

Ovitz, K., and T. R. Johnson. 2019. Seeking sustainability: employing Ostrom's SESF to explore spatial fit in Maine's sea urchin fishery. International Journal of the Commons 13:276-302. https://doi.org/10.18352/ijc.866

Pacilly, F. C. A., G. J. Hofstede, E. T. L. van Bueren, and J. C. J. Groot. 2019. Analysing social-ecological interactions in disease control: an agent-based model on farmers' decision making and potato late blight dynamics. Environmental Modelling \& Software 119:354-373. https://doi.org/10.1016/j.envsoft.2019.06.016

Paini, D. R. 2004. Impact of the introduced honey bee (Apis mellifera) (Hymenoptera: Apidae) on native bees: a review. Austral Ecology 29:399-407. https://doi.org/10.1111/j.1442-9993.2004.01376. $\underline{x}$

Paini, D. R., and J. D. Roberts. 2005. Commercial honey bees (Apis mellifera) reduce the fecundity of an Australian native bee (Hylaeus alcyoneus). Biological Conservation 123(1):103-112. https://doi.org/10.1016/j.biocon.2004.11.001

Partelow, S. 2016. Coevolving Ostrom's social-ecological systems (SES) framework and sustainability science: four key co-benefits. Sustainability Science 11:399-410. https://doi.org/10.1007/ $\underline{\text { s11625-015-0351-3 }}$

Partelow, S. 2018. A review of the social-ecological systems framework: applications, methods, modifications, and challenges. Ecology and Society 23(4):36. https://doi.org/10.5751/ES-10594-230436

Partelow, S., M. Fujitani, V. Soundararajan, and A. Schlüter. 2019. Transforming the social-ecological systems framework into a knowledge exchange and deliberation tool for comanagement. Ecology and Society 24(1):15. https://doi.org/10.5751/ES-10724-240115

Partelow, S., M. Glaser, S. Solano Arce, R. Sá Leitão Barboza, and A. Schlüter. 2018a. Mangroves, fishers, and the struggle for adaptive comanagement: applying the social-ecological systems framework to a marine extractive reserve (RESEX) in Brazil. Ecology and Society 23(3):19. https://doi.org/10.5751/es-10269-230319

Partelow, S., P. Senff, N. Buhari, and A. Schlüter. $2018 b$. Operationalizing the social-ecological systems framework in pond aquaculture. International Journal of the Commons 12:485-518. https://doi.org/10.18352/ijc.834

Patel, V., N. Pauli, E. Biggs, L. Barbour, and B. Boruff. 2020. Why bees are critical for achieving sustainable development. Ambio. https://doi.org/10.1007/s13280-020-01333-9

Pettit, N. E., R. J. Naiman, J. M. Fry, J. D. Roberts, P. G. Close, B. J. Pusey, G. S. Woodall, C. J. MacGregor, P. Speldewinde, B. Stewart, R. Dobbs, H. Paterson, P. Cook, S. Toussaint, S. Comer, and P. M. Davies. 2015. Environmental change: prospects for conservation and agriculture in a southwest Australia biodiversity hotspot. Ecology and Society 20(3):10. https://doi.org/10.5751/ ES-07727-200310

Phillips, C. 2014. Following beekeeping: more-than-human practice in agrifood. Journal of Rural Studies 36:149-159. https:// doi.org/10.1016/j.jrurstud.2014.06.013

Phillips, R. D., S. D. Hopper, and K. W. Dixon. 2010. Pollination ecology and the possible impacts of environmental change in the southwest Australian biodiversity hotspot. Philosophical Transactions of the Royal Society B: Biological Sciences 365:517-528. https://doi.org/10.1098/rstb.2009.0238

Pilati, L., and P. Fontana. 2018. Sequencing the movements of honey bee colonies between the forage sites with the microeconomic model of the migratory beekeeper. In R. E. Rebolledo Ranz, editor. Beekeeping: new challenges. IntechOpen. https://doi.org/10.5772/intechopen.80540

Pilati, L., and M. Prestamburgo. 2016. Sequential relationship between profitability and sustainability: the case of migratory beekeeping. Sustainability 8(1):94. https://doi.org/10.3390/ $\underline{\text { su} 8010094}$

Pitman, A. J., G. T. Narisma, R. A. Pielke Sr., and N. J. Holbrook. 2004. Impact of land cover change on the climate of southwest Western Australia. Journal of Geophysical Research: Atmospheres 109(D18). https://doi.org/10.1029/2003JD004347

Potts, S. G., V. Imperatriz-Fonseca, H. T. Ngo, M. A. Aizen, J. C. Biesmeijer, T. D. Breeze, L. V. Dicks, L. A. Garibaldi, R. Hill, J. Settele, and A. J. Vanbergen. 2016. Safeguarding pollinators and their values to human well-being. Nature 540:220-229. https://doi. org/10.1038/nature20588

Potts, S. G., S. P. M. Roberts, R. Dean, G. Marris, M. A. Brown, R. Jones, P. Neumann, and J. Settele. 2010. Declines of managed honey bees and beekeepers in Europe. Journal of Apicultural Research 49:15-22. https://doi.org/10.3896/IBRA.1.49.1.02

Rodela, R., C. M. Tucker, M. Šmid-Hribar, M. Sigura, N. Bogataj, M. Urbanc, and A. Gunya. 2019. Intersections of ecosystem services and common-pool resources literature: an interdisciplinary encounter. Environmental Science \& Policy 94:72-81. https://doi. org/10.1016/j.envsci.2018.12.021

Roshan, N., T. Rippers, C. Locher, and K. A. Hammer. 2017. Antibacterial activity and chemical characteristics of several Western Australian honeys compared to manuka honey and pasture honey. Archives of Microbiology 199:347-355. https://doi. org/10.1007/s00203-016-1308-3

Rova, S., and F. Pranovi. 2017. Analysis and management of multiple ecosystem services within a social-ecological context. 
Ecological Indicators 72:436-443. https://doi.org/10.1016/j. ecolind.2016.07.050

Salvin, S. 2015. Compatibility of management objectives on public lands with beekeeping. Honeybee and pollination program. Rural Industries Research and Development Corporation, Canberra, Australia. [online] URL: https://www.agrifutures.com.au/wpcontent/uploads/publications/15-024.pdf

Sánchez-Bayo, F. and K. A. G. Wyckhuys 2019. Worldwide decline of the entomofauna: a review of its drivers. Biological Conservation 232:8-27. https://doi.org/10.1016/i.biocon.2019.01.020

Saunders, M. E., T. J. Smith, and R. Rader. 2018. Bee conservation: key role of managed bees. Science 360:389. https:// doi.org/10.1126/science.aat1535

Shedley, E., N. Burrows, C. J. Yates, and D. J. Coates. 2018. Using bioregional variation in fire history and fire response attributes as a basis for managing threatened flora in a fire-prone Mediterranean climate biodiversity hotspot. Australian Journal of Botany 66:134-143. https://doi.org/10.1071/BT17176

Siebert, J. W. 1980. Beekeeping, pollination, and externalities in California agriculture. American Journal of Agricultural Economics 62:165-171. https://doi.org/10.2307/1239682

Smart, M., J. Pettis, N. Rice, Z. Browning, and M. Spivak. 2016. Linking measures of colony and individual honey bee health to survival among apiaries exposed to varying agricultural land use. PLoS ONE 11:e0152685. https://doi.org/10.1371/journal. pone. 0152685

Smith, F. G. 1969. Honey plants in Western Australia. Department of Primary Industries and Regional Development, Perth, Australia. [online] URL: https://researchlibrary.agric.wa.gov.au/ bulletins $3 / 4 /$

Smith, I., and S. Power. 2014. Past and future changes to inflows into Perth (Western Australia) dams. Journal of Hydrology: Regional Studies 2:84-96. https://doi.org/10.1016/j.ejrh.2014.08.005

Soares, S., J. S. Amaral, M. B. P. Oliveira, and I. Mafra. 2017. A comprehensive review on the main honey authentication issues: production and origin. Comprehensive Reviews in Food Science and Food Safety 16:1072-1100. https://doi.org/10.1111/1541-4337.12278

Somerville, D. C., and D. Nicholson 2005. The primary melliferous flora and other aspects associated with beekeeping within state forests of New South Wales as determined by surveys of beekeepers. Australian Forestry 68:9-16. https://doi. org/10.1080/00049158.2005.10676220

Sponsler, D. B., and R. M. Johnson. 2015. Honey bee success predicted by landscape composition in Ohio, USA. PeerJ 3:e838. https://doi.org/10.7717/peerj.838

Stojanovic, T., H. McNae, P. Tett, T. W. Potts, J. Reis, H. D. Smith, and I. Dillingham. 2016. The "social" aspect of social-ecological systems: a critique of analytical frameworks and findings from a multisite study of coastal sustainability. Ecology and Society 21 (3):15. https://doi.org/10.5751/es-08633-210315

Switanek, M., K. Crailsheim, H. Truhetz, and R. Brodschneider. 2017. Modelling seasonal effects of temperature and precipitation on honey bee winter mortality in a temperate climate. Science of the Total Environment 579:1581-1587. https://doi.org/10.1016/j. scitotenv.2016.11.178

Uchiyama, Y., H. Matsuoka, and R. Kohsaka. 2017. Apiculture knowledge transmission in a changing world: Can family-owned knowledge be opened? Journal of Ethnic Foods 4:262-267. https:// doi.org/10.1016/j.jef.2017.09.002

Valido, A., M. C. Rodríguez-Rodríguez, and P. Jordano. 2019. Honeybees disrupt the structure and functionality of plantpollinator networks. Scientific Reports 9:4711. https://doi. org/10.1038/s41598-019-41271-5

Van Dijk, J., J. Gomboso, and C. Levantis. 2016. Australian honey bee industry: 2014-15 survey results. Australian Bureau of Agricultural and Resource Economics and Sciences, Canberra, Australia. [online] URL: http://data.daff.gov.au/data/warehouse/9aas/2016/ HoneyBeeIndustry/AusHoneyBeeIndustry 2014-15 v1.1.0.docx

vanEngelsdorp, D., and M. D. Meixner. 2010. A historical review of managed honey bee populations in Europe and the United States and the factors that may affect them. Journal of Invertebrate Pathology 103:S80-S95. https://doi.org/10.1016/j.jip.2009.06.011

Vinci, G., M. Rapa, and F. Roscioli. 2018. Sustainable development in rural areas of Mexico through beekeeping. International Journal of Science and Engineering Invention 4 (8):1-7.

Vogt, J. M., G. B. Epstein, S. K. Mincey, B. C. Fischer, and P. McCord. 2015. Putting the "E" in SES: unpacking the ecology in the Ostrom social-ecological system framework. Ecology and Society 20(1):55. https://doi.org/10.5751/ES-07239-200155

Wagner, D. L. 2020. Insect declines in the Anthropocene. Annual Review of Entomology 65:457-480. https://doi.org/10.1146/ annurev-ento-011019-025151

Yap, N., F. J. Delvin, G. Otis, and V. T. Dang. 2015. Beekeeping, well-being, transformative change: development benefits according to small farmers in Vietnam. Journal of Rural and Community Development 10:19-31. 
Appendix 1: SESF variables for beekeeping SES are listed with their definitions and methods used to identify them.

Sources are listed if variable is found in published or unpublished literature. Note that both, SESF guiding literature and literature looking at bee systems explored to identify variables. In addition to literature, online sources such as government websites, rules and regulations had also supported variable identification process,

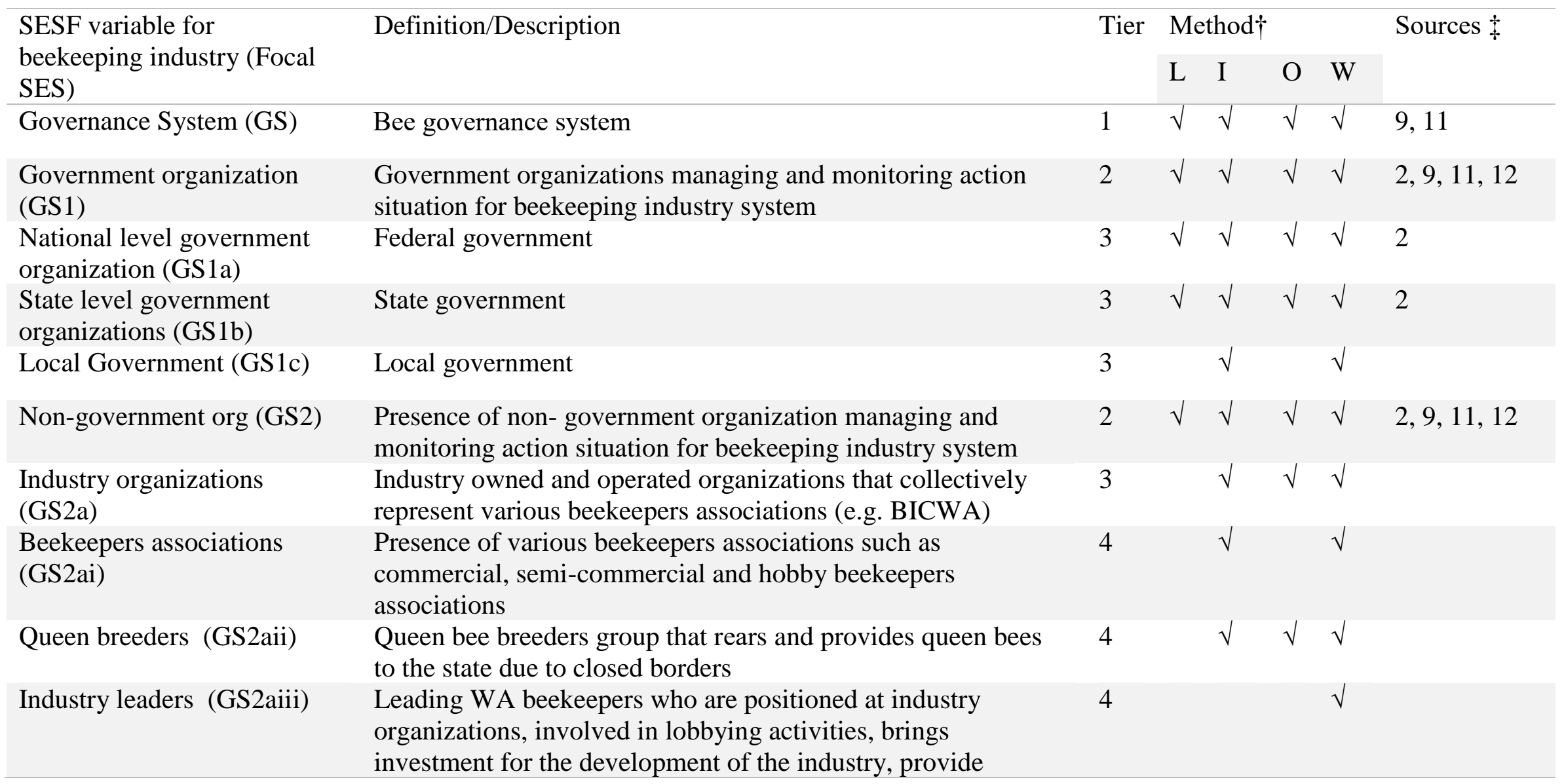


Research organizations

(GS2b)

University research (GS2bi)

Industry funded research

(GS2bii)

Cooperative Research centres

(CRCs)

Network Structure (GS3)

Social network (GS3a)

Informal beekeeper groups

(GS3ai)

Market network (GS3b)

Local farmers' market

(GS3bi)

Supermarkets (GS3bii)

Export market (GS3biii)

Property rights systems (GS4)

Operational choice rules

(GS5)

Collective choice rules (GS6)

Constitutional choice rules (GS7)

Act relating to beekeeping activity (GS7a) knowledge about resources and beekeeping techniques to new beekeepers

Organizations actively engaged in research related to various aspects of the beekeeping industry

Student and researchers from universities involved in the research beneficial to the beekeeping industry

Research funded by industry owned and operated organizations (targets industry specific issues, beekeeper researchers)

Collaborative research involvement from government, nongovernment organizations (e.g. CRC for honeybee products) Social or political connections among government / nogovernment organizations, beekeepers and other industry stakeholders.

Social connections between beekeepers and government or private land owners/managers

Information flows among groups of beekeepers (e.g. information regarding resource availability and access)

Presence or absences of multilevel of market structure and associated interactions

Regular or occasional local markets and fresh food produce outlets

Supermarket networks

Export market and associated interactions

Presence of property rights system governing access to forage resources (e.g. private property, common property, restricted access)

Presence of formal written rules for access and/or harvesting from the forage resources

Rules defined by involved stakeholders following their

understanding of local social, ecological and political conditions

Law, act or mandates defined by regional or national level government

Biosecurity and Agriculture Management Act 2007

\section{3} $\sqrt{ }$

\section{7}

4

4

4

2

$\sqrt{ } \sqrt{ }$

$2,9,11,12$

\begin{tabular}{|c|c|c|c|c|c|}
\hline 3 & $\sqrt{ }$ & $\sqrt{ }$ & $\sqrt{ }$ & $\sqrt{ }$ & 2 \\
\hline 4 & & $\sqrt{ }$ & & $\sqrt{ }$ & \\
\hline 3 & & $\sqrt{ }$ & & & \\
\hline 4 & & $\sqrt{ }$ & & $\sqrt{ }$ & \\
\hline 4 & & $\sqrt{ }$ & & $\sqrt{ }$ & \\
\hline 4 & & $\sqrt{ }$ & $\sqrt{ }$ & $\sqrt{ }$ & \\
\hline 2 & $\sqrt{ }$ & $\sqrt{ }$ & $\sqrt{ }$ & $\sqrt{ }$ & $2,9,11,12$ \\
\hline 2 & $\sqrt{ }$ & $\sqrt{ }$ & $\sqrt{ }$ & $\sqrt{ }$ & $2,9,11,12$ \\
\hline 2 & $\sqrt{ }$ & & $\sqrt{ }$ & $\sqrt{ }$ & $2,9,11,12$ \\
\hline 2 & $\sqrt{ }$ & $\sqrt{ }$ & $\sqrt{ }$ & $\sqrt{ }$ & $2,9,11,12$ \\
\hline 3 & & $\sqrt{ }$ & $\sqrt{ }$ & $\sqrt{ }$ & 19 \\
\hline
\end{tabular}




\begin{tabular}{|c|c|c|c|c|c|c|c|}
\hline $\begin{array}{l}\text { Act relating to biosecurity } \\
(\mathrm{GS} 7 \mathrm{~b})\end{array}$ & Biosecurity and Agriculture Management Regulation 2013 & 3 & & $\sqrt{ }$ & $\sqrt{ }$ & $\sqrt{ }$ & 19 \\
\hline $\begin{array}{l}\text { Acts relating to access and } \\
\text { use of resources }(\mathrm{GS} 7 \mathrm{c})\end{array}$ & $\begin{array}{l}\text { Conservation and land management Act 1984, , Biodiversity } \\
\text { Conservation Act } 2016 \text { and Biodiversity Conservation } \\
\text { Regulations } 2018\end{array}$ & 3 & $\sqrt{ }$ & $\sqrt{ }$ & $\sqrt{ }$ & $\sqrt{ }$ & 22 \\
\hline $\begin{array}{l}\text { Conditions for using } \\
\text { resources available on } \\
\text { Government owned land } \\
\text { (GS7ci) }\end{array}$ & $\begin{array}{l}\text { General Conditions for using Apiary Authorities on Crown land } \\
\text { in Western Australia }\end{array}$ & 4 & $\sqrt{ }$ & $\sqrt{ }$ & $\sqrt{ }$ & $\sqrt{ }$ & 24 \\
\hline $\begin{array}{l}\text { Forest management plans } \\
\text { (GS7cii) }\end{array}$ & Planning for management of forest used for apiary authority & 4 & & $\sqrt{ }$ & $\sqrt{ }$ & $\sqrt{ }$ & 20 \\
\hline $\begin{array}{l}\text { Local government Acts or } \\
\text { Bylaws (GS7ciii) }\end{array}$ & $\begin{array}{l}\text { Verge treatment/spraying, regulations relating to keeping bees } \\
\text { in neighbourhood }\end{array}$ & 4 & & $\sqrt{ }$ & & $\sqrt{ }$ & \\
\hline $\begin{array}{l}\text { Conditions for using } \\
\text { resources managed by } \\
\text { managers other than } \\
\text { government (GS7civ) }\end{array}$ & Recreation, mining, timber and logging, pastoral leases & 4 & $\sqrt{ }$ & $\sqrt{ }$ & $\sqrt{ }$ & $\sqrt{ }$ & 23 \\
\hline $\begin{array}{l}\text { Requirements relating to food } \\
\text { handling, processing and } \\
\text { labelling (GS7d) }\end{array}$ & $\begin{array}{l}\text { Regulation for extraction, processing, packing and labelling } \\
\text { of honey }\end{array}$ & 3 & & $\sqrt{ }$ & & $\sqrt{ }$ & 21 \\
\hline $\begin{array}{l}\text { Monitoring and sanctioning } \\
\text { rules (GS8) }\end{array}$ & $\begin{array}{l}\text { Presence of authority to for resource monitoring and access } \\
\text { sanctioning }\end{array}$ & 2 & $\sqrt{ }$ & $\sqrt{ }$ & $\sqrt{ }$ & $\sqrt{ }$ & $2,9,11,12$ \\
\hline Sanctioning rules (GS8a) & Process of sanctioning authority to access the resources & 3 & $\sqrt{ }$ & $\sqrt{ }$ & $\sqrt{ }$ & $\sqrt{ }$ & 2 \\
\hline Apiary permits (GS8ai) & Authority to place beehives on forage locations & 4 & $\sqrt{ }$ & $\sqrt{ }$ & $\sqrt{ }$ & $\sqrt{ }$ & 16,26 \\
\hline Clearing permits (GS8aii) & $\begin{array}{l}\text { Authority to clear vegetation to gain physical access and place } \\
\text { beehives on forage locations }\end{array}$ & 4 & $\sqrt{ }$ & $\sqrt{ }$ & $\sqrt{ }$ & $\sqrt{ }$ & 24 \\
\hline Monitoring rules (GS8b) & Process of monitoring resource availability and usage & 3 & $\sqrt{ }$ & $\sqrt{ }$ & & $\sqrt{ }$ & 2 \\
\hline $\begin{array}{l}\text { Apiary site monitoring } \\
\text { (GS8bi) }\end{array}$ & Monitoring resource use on apiary authority & 4 & & $\sqrt{ }$ & & $\sqrt{ }$ & \\
\hline Monitoring beehives (GS8bii) & Monitoring requirement and availability of required resources & 4 & & $\sqrt{ }$ & & $\sqrt{ }$ & \\
\hline Actors (A) & Beekeepers & 1 & $\sqrt{ }$ & $\sqrt{ }$ & $\sqrt{ }$ & $\sqrt{ }$ & $7,9,11$ \\
\hline
\end{tabular}




\begin{tabular}{|c|c|c|c|c|c|c|c|}
\hline Number of actors (A1) & Number of beekeepers & 2 & $\sqrt{ }$ & $\sqrt{ }$ & $\sqrt{ }$ & $\sqrt{ }$ & 9,12 \\
\hline $\begin{array}{l}\text { Socio-economic attributes } \\
\text { (A2) }\end{array}$ & Socio-economic characteristics of beekeepers & 2 & $\sqrt{ }$ & $\sqrt{ }$ & $\sqrt{ }$ & $\sqrt{ }$ & $2,9,11,12$ \\
\hline Demographic attributes (A2a) & Age of beekeepers & 3 & $\sqrt{ }$ & $\sqrt{ }$ & $\sqrt{ }$ & $\sqrt{ }$ & 2,13 \\
\hline $\begin{array}{l}\text { Intergenerational beekeeper } \\
\text { (A2ai) }\end{array}$ & Beekeeping generation & 4 & & $\sqrt{ }$ & $\sqrt{ }$ & $\sqrt{ }$ & \\
\hline Economic attributes (A2b) & Economic characteristic of beekeeper & 3 & $\sqrt{ }$ & $\sqrt{ }$ & $\sqrt{ }$ & $\sqrt{ }$ & 2 \\
\hline Large-scale operators (A2bi) & Beekeepers more than 500 hives & 4 & & $\sqrt{ }$ & $\sqrt{ }$ & $\sqrt{ }$ & \\
\hline Small-scale operators (A2bii) & Beekeeper less than 500 hives & 4 & & $\sqrt{ }$ & $\sqrt{ }$ & $\sqrt{ }$ & \\
\hline $\begin{array}{l}\text { Equipment } \\
\text { manufacturer/supplier } \\
\text { (A2biii) }\end{array}$ & $\begin{array}{l}\text { Manufacturer / supplier of beekeeping equipment (May or may } \\
\text { not be keeping bees) }\end{array}$ & 4 & & $\sqrt{ }$ & & $\sqrt{ }$ & \\
\hline $\begin{array}{l}\text { Producer, packers and queen } \\
\text { bee breeders (A2biv) }\end{array}$ & Beekeepers involved in honey packing or queen breeding & 4 & & $\sqrt{ }$ & $\sqrt{ }$ & $\sqrt{ }$ & \\
\hline Social attributes $(\mathrm{A} 2 \mathrm{c})$ & Presence of mutual support, cooperation and leadership quality & 3 & $\sqrt{ }$ & $\sqrt{ }$ & $\sqrt{ }$ & $\sqrt{ }$ & 2 \\
\hline $\begin{array}{l}\text { History of past experience } \\
\text { (A3) }\end{array}$ & Duration of involvement in beekeeping & 2 & $\sqrt{ }$ & $\sqrt{ }$ & $\sqrt{ }$ & $\sqrt{ }$ & $2,9,11,12$ \\
\hline Location (A4) & Residential location of beekeepers & 2 & $\sqrt{ }$ & $\sqrt{ }$ & $\sqrt{ }$ & $\sqrt{ }$ & $2,9,11,12$ \\
\hline $\begin{array}{l}\text { Leadership/ Entrepreneurship } \\
\text { (A5) }\end{array}$ & $\begin{array}{l}\text { Presence of educated and well-connected leader who is } \\
\text { respected by their peers }\end{array}$ & 2 & $\sqrt{ }$ & $\sqrt{ }$ & $\sqrt{ }$ & $\sqrt{ }$ & $2,9,11,12$ \\
\hline Volunteer leaders (A5a) & Active beekeeper to lead collective action & 3 & & $\sqrt{ }$ & $\sqrt{ }$ & $\sqrt{ }$ & \\
\hline $\begin{array}{l}\text { Training for beekeeping } \\
\text { business (A5b) }\end{array}$ & $\begin{array}{l}\text { Beekeeper involved in providing formal/informal training for } \\
\text { new beekeepers }\end{array}$ & 3 & & $\sqrt{ }$ & & $\sqrt{ }$ & \\
\hline Norms and social capital (A6) & Closeness of community & 2 & $\sqrt{ }$ & $\sqrt{ }$ & $\sqrt{ }$ & $\sqrt{ }$ & $2,9,11,12$ \\
\hline Social interaction (A6a) & Interactions and knowledge exchange among beekeepers & 3 & & $\sqrt{ }$ & & $\sqrt{ }$ & \\
\hline Trust among actors (A6b) & Level of trust among beekeepers & 3 & & $\sqrt{ }$ & $\sqrt{ }$ & $\sqrt{ }$ & \\
\hline $\begin{array}{l}\text { Relationship with other actors } \\
\text { (A6c) }\end{array}$ & $\begin{array}{l}\text { Relationship of beekeepers with actors other than the focal SES } \\
\text { (e.g. farmers, local residents, consumers) }\end{array}$ & 3 & & $\sqrt{ }$ & & $\sqrt{ }$ & \\
\hline
\end{tabular}




\begin{tabular}{|c|c|c|c|c|c|c|c|}
\hline $\begin{array}{l}\text { Knowledge of SES models } \\
\text { (A7) }\end{array}$ & Presence/ degree of Local ecological knowledge (LEK) & 2 & $\sqrt{ }$ & $\sqrt{ }$ & $\sqrt{ }$ & $\sqrt{ }$ & $2,9,11,12$ \\
\hline $\begin{array}{l}\text { Local knowledge on SES } \\
\text { (A7a) }\end{array}$ & $\begin{array}{l}\text { Spatial- temporal knowledge of floral source and understanding } \\
\text { of effects of beekeeping activities on local environment }\end{array}$ & 3 & $\sqrt{ }$ & $\sqrt{ }$ & $\sqrt{ }$ & $\sqrt{ }$ & 2,12 \\
\hline $\begin{array}{l}\text { Knowledge of concepts such } \\
\text { as conservation, human- } \\
\text { nature relationships (A7b) }\end{array}$ & $\begin{array}{l}\text { Presence / degree of understanding of concepts like } \\
\text { conservation, ecosystem services and human-nature } \\
\text { relationship }\end{array}$ & 3 & $\sqrt{ }$ & $\sqrt{ }$ & $\sqrt{ }$ & $\sqrt{ }$ & 2,12 \\
\hline $\begin{array}{l}\text { Knowledge of the biological } \\
\text { shocks on SES (A7c) }\end{array}$ & $\begin{array}{l}\text { Level of knowledge of the potential and real disturbance } \\
\text { patterns and its possible effects }\end{array}$ & 3 & $\sqrt{ }$ & $\sqrt{ }$ & $\sqrt{ }$ & $\sqrt{ }$ & 2,12 \\
\hline $\begin{array}{l}\text { Importance of resource } \\
\text { (dependence) (A8) }\end{array}$ & Livelihood dependence on bee resources & 2 & $\sqrt{ }$ & $\sqrt{ }$ & $\sqrt{ }$ & $\sqrt{ }$ & $2,9,11,12$ \\
\hline Full-time operators (A8a) & Completely depend on beekeeping for livelihood & 3 & & $\sqrt{ }$ & $\sqrt{ }$ & $\sqrt{ }$ & \\
\hline Part-time operators (A8b) & Has a source of income other than beekeeping & 3 & & $\sqrt{ }$ & $\sqrt{ }$ & $\sqrt{ }$ & \\
\hline Technologies available (A9) & $\begin{array}{l}\text { Technologies used to identify, extract, harvest and manage the } \\
\text { resource (A9) }\end{array}$ & 2 & $\sqrt{ }$ & $\sqrt{ }$ & $\sqrt{ }$ & $\sqrt{ }$ & $2,9,11,12$ \\
\hline Resource system (RS) & Bee resources - Resources that produce melliferous flora & 1 & $\sqrt{ }$ & $\sqrt{ }$ & $\sqrt{ }$ & $\sqrt{ }$ & $7,9,11$ \\
\hline Sector (RS1) & Bee resources available on various sector (e.g. forest) & 2 & $\sqrt{ }$ & $\sqrt{ }$ & $\sqrt{ }$ & $\sqrt{ }$ & $2,9,11,12$ \\
\hline Forest flora (RS1a) & $\begin{array}{l}\text { Bee resources available from trees and other understorey } \\
\text { plants in forest }\end{array}$ & 3 & $\sqrt{ }$ & $\sqrt{ }$ & $\sqrt{ }$ & $\sqrt{ }$ & 7 \\
\hline Agriculture flora (RS1b) & Bee resources available from agriculture crops & 3 & $\sqrt{ }$ & $\sqrt{ }$ & $\sqrt{ }$ & $\sqrt{ }$ & 7 \\
\hline Other plantation (RS1c) & Bee resources available from plantation & 3 & $\sqrt{ }$ & $\sqrt{ }$ & $\sqrt{ }$ & $\sqrt{ }$ & 7 \\
\hline Revegetation (RS1ci) & Bee resources available from revegetation & 4 & $\sqrt{ }$ & $\sqrt{ }$ & $\sqrt{ }$ & $\sqrt{ }$ & 7 \\
\hline Verge plantation (RS1cii) & $\begin{array}{l}\text { Bee resources available from plantation on new or existing } \\
\text { verge }\end{array}$ & 4 & $\sqrt{ }$ & $\sqrt{ }$ & & $\sqrt{ }$ & 6 \\
\hline $\begin{array}{l}\text { Clarity of system boundary } \\
\text { (RS2) }\end{array}$ & $\begin{array}{l}\text { Clarity of the system's geographical, social and legal } \\
\text { boundaries }\end{array}$ & 2 & $\sqrt{ }$ & $\sqrt{ }$ & $\sqrt{ }$ & $\sqrt{ }$ & $2,9,11,12$ \\
\hline $\begin{array}{l}\text { Geographic boundaries } \\
(\mathrm{RS} 2 \mathrm{a})\end{array}$ & Geographic boundary of bee resources & 3 & $\sqrt{ }$ & & & & 2 \\
\hline $\begin{array}{l}\text { Anthropogenic boundaries } \\
\text { (RS2b) }\end{array}$ & Fences or other human constructed boundaries & 3 & $\sqrt{ }$ & $\sqrt{ }$ & $\sqrt{ }$ & $\sqrt{ }$ & 2 \\
\hline
\end{tabular}




\begin{tabular}{|c|c|c|c|c|c|c|c|}
\hline $\begin{array}{l}\text { Individual's resource access } \\
\text { boundary }(\mathrm{RS} 2 \mathrm{c})\end{array}$ & User-defined boundary for the bee resources & 3 & $\sqrt{ }$ & $\sqrt{ }$ & $\sqrt{ }$ & $\sqrt{ }$ & 2,18 \\
\hline $\begin{array}{l}\text { Size of the resource system } \\
(\mathrm{RS} 3)\end{array}$ & Spatial extent and its area of bee resources & 2 & $\sqrt{ }$ & $\sqrt{ }$ & $\sqrt{ }$ & $\sqrt{ }$ & $2,9,11,12$ \\
\hline $\begin{array}{l}\text { Area covered by geographic } \\
\text { extent of bee resources } \\
\text { (RS3a) }\end{array}$ & Total area for bee resources & 3 & $\sqrt{ }$ & $\sqrt{ }$ & $\sqrt{ }$ & $\sqrt{ }$ & 18 \\
\hline $\begin{array}{l}\text { Size of different types of } \\
\text { ecosystems within the extent } \\
\text { of bee resources (RS3b) }\end{array}$ & Total area for each sector of bee resources & 3 & $\sqrt{ }$ & & $\sqrt{ }$ & & 18 \\
\hline $\begin{array}{l}\text { Fragmentation dynamics } \\
(\mathrm{RS} 3 \mathrm{c})\end{array}$ & Frequency of fragmentation over time & 3 & $\sqrt{ }$ & & $\sqrt{ }$ & & 18 \\
\hline $\begin{array}{l}\text { Human constructed facilities } \\
\text { (RS4) }\end{array}$ & $\begin{array}{l}\text { Anthropogenic structures supporting resource access and } \\
\text { management }\end{array}$ & 2 & $\sqrt{ }$ & $\sqrt{ }$ & $\sqrt{ }$ & $\sqrt{ }$ & $2,9,11,12$ \\
\hline $\begin{array}{l}\text { Infrastructure e.g. road, } \\
\text { highways (RS4a) }\end{array}$ & $\begin{array}{l}\text { Availability of infrastructure for movement (e.g. roads, access } \\
\text { ways) or as impediments (e.g. dams, fence) }\end{array}$ & 3 & $\sqrt{ }$ & $\sqrt{ }$ & $\sqrt{ }$ & $\sqrt{ }$ & 2,18 \\
\hline Water resources $(\mathrm{RS} 4 \mathrm{~b})$ & Proximity to the nearest water resources & 3 & & $\sqrt{ }$ & & $\sqrt{ }$ & \\
\hline Other facilities (RS4c) & Recreation facilities & 3 & & $\sqrt{ }$ & & $\sqrt{ }$ & \\
\hline $\begin{array}{l}\text { Productivity of the system } \\
\text { (RS5) }\end{array}$ & Estimation about potential productivity of the area & 2 & $\sqrt{ }$ & $\sqrt{ }$ & $\sqrt{ }$ & $\sqrt{ }$ & $2,9,11,12$ \\
\hline Resource dynamics (RS5a) & Regularity of flowering events & 3 & $\sqrt{ }$ & $\sqrt{ }$ & $\sqrt{ }$ & $\sqrt{ }$ & 18 \\
\hline $\begin{array}{l}\text { Natural resource dynamics } \\
\text { (RS5ai) }\end{array}$ & $\begin{array}{l}\text { Natural availability or unavailability of flowering event e.g. } \\
\text { annual, biannual flowering frequency }\end{array}$ & 4 & & $\sqrt{ }$ & $\sqrt{ }$ & $\sqrt{ }$ & \\
\hline $\begin{array}{l}\text { Resource dynamics in } \\
\text { response to human } \\
\text { disturbances (RS5aii) }\end{array}$ & $\begin{array}{l}\text { Availability or unavailability of flowering due to man-made } \\
\text { changes e.g. flowering event after species recovery from } \\
\text { prescribed fire }\end{array}$ & 4 & & $\sqrt{ }$ & $\sqrt{ }$ & $\sqrt{ }$ & \\
\hline Resource diversity (RS5b) & Diversity of bee flora species & 3 & $\sqrt{ }$ & $\sqrt{ }$ & $\sqrt{ }$ & $\sqrt{ }$ & 1 \\
\hline $\begin{array}{l}\text { Equilibrium properties of the } \\
\text { system (RS6) }\end{array}$ & $\begin{array}{l}\text { Positive or negative influences on the equilibrium of the bee } \\
\text { resources (e.g. seasonality, rainfall trends) }\end{array}$ & 2 & $\sqrt{ }$ & $\sqrt{ }$ & $\sqrt{ }$ & $\sqrt{ }$ & $2,9,11,12$ \\
\hline $\begin{array}{l}\text { Frequency of disturbances } \\
\text { (RS6a) }\end{array}$ & $\begin{array}{l}\text { Frequency of external impacts and system response e.g. } \\
\text { frequency of draught/fire events and species recovery }\end{array}$ & 3 & $\sqrt{ }$ & $\sqrt{ }$ & $\sqrt{ }$ & $\sqrt{ }$ & 18 \\
\hline Extent of disturbances (RS6b) & $\begin{array}{l}\text { Extent of external impacts and system response e.g. extent of } \\
\text { draught/fire events and species recovery }\end{array}$ & 3 & $\sqrt{ }$ & $\sqrt{ }$ & $\sqrt{ }$ & $\sqrt{ }$ & 18 \\
\hline
\end{tabular}




\begin{tabular}{|c|c|c|c|c|c|c|c|}
\hline $\begin{array}{l}\text { Intensity of disturbances } \\
\text { (RS6c) }\end{array}$ & $\begin{array}{l}\text { Intensity of external impacts and system response e.g. Intensity } \\
\text { of draught/fire events and species recovery }\end{array}$ & 3 & $\sqrt{ }$ & $\sqrt{ }$ & $\sqrt{ }$ & $\sqrt{ }$ & 18 \\
\hline $\begin{array}{l}\text { Predictability of system } \\
\text { dynamics (RS7) }\end{array}$ & $\begin{array}{l}\text { Degree to which beekeepers are able to forecast/identify } \\
\text { patterns in productivity of bee resources }\end{array}$ & 2 & $\sqrt{ }$ & $\sqrt{ }$ & $\sqrt{ }$ & $\sqrt{ }$ & $2,9,11,12$ \\
\hline $\begin{array}{l}\text { Probability of driving forces } \\
\text { leading to system dynamics } \\
\text { (RS7a) }\end{array}$ & $\begin{array}{l}\text { Probability of driving forces e.g. uncertain nature of rainfall or } \\
\text { natural fire events }\end{array}$ & 3 & $\sqrt{ }$ & $\sqrt{ }$ & $\sqrt{ }$ & $\sqrt{ }$ & 18 \\
\hline $\begin{array}{l}\text { Variability of driving forces } \\
\text { leading to system dynamics } \\
\text { (RS7b) }\end{array}$ & Variability of driving force e.g. variation in nectar production & 3 & $\sqrt{ }$ & $\sqrt{ }$ & $\sqrt{ }$ & $\sqrt{ }$ & 18 \\
\hline Storage characteristics (RS8) & $\begin{array}{l}\text { Information storage regarding effects of disturbances on bee } \\
\text { resources }\end{array}$ & 2 & $\sqrt{ }$ & $\sqrt{ }$ & $\sqrt{ }$ & $\sqrt{ }$ & $2,9,11,12$ \\
\hline $\begin{array}{l}\text { Location and association } \\
\text { (RS9) }\end{array}$ & $\begin{array}{l}\text { Spatial configuration and extent of bee flora where system can } \\
\text { be accessed by the beekeepers }\end{array}$ & 2 & $\sqrt{ }$ & $\sqrt{ }$ & $\sqrt{ }$ & $\sqrt{ }$ & $\begin{array}{l}2,9,11,12, \\
18\end{array}$ \\
\hline Ecosystem history (RS10) & History of ecosystem dynamics & 2 & $\sqrt{ }$ & $\sqrt{ }$ & $\sqrt{ }$ & $\sqrt{ }$ & 18 \\
\hline $\begin{array}{l}\text { History of natural disasters } \\
\text { (RS10a) }\end{array}$ & History of draught or bush fire events & 3 & $\sqrt{ }$ & $\sqrt{ }$ & $\sqrt{ }$ & $\sqrt{ }$ & 18 \\
\hline $\begin{array}{l}\text { History of anthropogenic use } \\
\text { and disturbances (RS10b) }\end{array}$ & History of prescribe burn events & 3 & $\sqrt{ }$ & $\sqrt{ }$ & $\sqrt{ }$ & $\sqrt{ }$ & 18 \\
\hline Resource unit (RU) & Beehives managed by beekeepers & 1 & $\sqrt{ }$ & $\sqrt{ }$ & $\sqrt{ }$ & $\sqrt{ }$ & $5,9,11$ \\
\hline $\begin{array}{l}\text { Mobility of Resource units } \\
\text { (RU1) }\end{array}$ & Beehive migration patterns & 2 & $\sqrt{ }$ & $\sqrt{ }$ & $\sqrt{ }$ & $\sqrt{ }$ & $2,9,11,12$ \\
\hline $\begin{array}{l}\text { Stationary Resource units } \\
\text { (RU1a) }\end{array}$ & Stationary (non-migratory) beehives & 3 & $\sqrt{ }$ & $\sqrt{ }$ & & $\sqrt{ }$ & 18 \\
\hline $\begin{array}{l}\text { Mobile Resource units } \\
\text { (RU1b) }\end{array}$ & Migration patterns of beehives & 3 & $\sqrt{ }$ & $\sqrt{ }$ & $\sqrt{ }$ & $\sqrt{ }$ & $9,11,18$ \\
\hline $\begin{array}{l}\text { Growth or replacement rate } \\
\text { (RU2) }\end{array}$ & $\begin{array}{l}\text { Absolute or relative descriptions of changes in quantities }(x) \text { of } \\
\text { beehives over time }(t)\end{array}$ & 2 & $\sqrt{ }$ & $\sqrt{ }$ & $\sqrt{ }$ & $\sqrt{ }$ & $2,9,11,12$ \\
\hline $\begin{array}{l}\text { Interactions among resource } \\
\text { units (RU3) }\end{array}$ & $\begin{array}{l}\text { Interactions among beehives managed by same or different } \\
\text { beekeeper }\end{array}$ & 2 & $\sqrt{ }$ & $\sqrt{ }$ & $\sqrt{ }$ & $\sqrt{ }$ & $2,9,11,12$ \\
\hline $\begin{array}{l}\text { Intraspecific interaction } \\
\text { (RU3a) }\end{array}$ & $\begin{array}{l}\text { Resource competition within honeybee species e.g. Hive } \\
\text { robbing }\end{array}$ & 3 & $\sqrt{ }$ & $\sqrt{ }$ & $\sqrt{ }$ & $\sqrt{ }$ & 18 \\
\hline
\end{tabular}




\begin{tabular}{|c|c|c|c|c|c|c|c|}
\hline $\begin{array}{l}\text { Proximity of resource units } \\
\text { (RU3ai) }\end{array}$ & Inter/intra colony distance among beehives & 4 & $\sqrt{ }$ & $\sqrt{ }$ & & $\sqrt{ }$ & 10,24 \\
\hline $\begin{array}{l}\text { Interactions damaging } \\
\text { resource unit conditions } \\
\text { (RU3aii) }\end{array}$ & Potential for disease transmission & 4 & $\sqrt{ }$ & $\sqrt{ }$ & & $\sqrt{ }$ & 10 \\
\hline $\begin{array}{l}\text { Interspecific resource } \\
\text { competition (RU3b) }\end{array}$ & $\begin{array}{l}\text { Resource competition among nectarivorous species e.g. for } \\
\text { nesting or forage resources }\end{array}$ & 3 & $\sqrt{ }$ & $\sqrt{ }$ & $\sqrt{ }$ & $\sqrt{ }$ & 18 \\
\hline Value of resource unit (RU4) & Value of a beehive & 2 & $\sqrt{ }$ & $\sqrt{ }$ & $\sqrt{ }$ & $\sqrt{ }$ & $2,9,11,12$ \\
\hline Market value (RU4a) & Cost associated with a beehive (e.g. levy, insurance etc.) & 3 & $\sqrt{ }$ & $\sqrt{ }$ & $\sqrt{ }$ & $\sqrt{ }$ & 2 \\
\hline Environmental value (RU4b) & $\begin{array}{l}\text { Non-monatory value of a beehive (e.g. importance for } \\
\text { pollination) }\end{array}$ & 3 & $\sqrt{ }$ & $\sqrt{ }$ & $\sqrt{ }$ & $\sqrt{ }$ & 2 \\
\hline Strategic value (RU4c) & Social/cultural value of a beehive (e.g. importance as a hobby) & 3 & $\sqrt{ }$ & $\sqrt{ }$ & $\sqrt{ }$ & $\sqrt{ }$ & 2 \\
\hline Number of units (RU5) & Number of managed hives & 2 & $\sqrt{ }$ & $\sqrt{ }$ & $\sqrt{ }$ & $\sqrt{ }$ & $2,9,11,12$ \\
\hline $\begin{array}{l}\text { Number of units leading to } \\
\text { economic benefit (RU5a) }\end{array}$ & Hives managed for economic benefits & 3 & & $\sqrt{ }$ & & $\sqrt{ }$ & \\
\hline Load size (RU5ai) & Number of hives managed for honey production & 4 & & $\sqrt{ }$ & & $\sqrt{ }$ & \\
\hline $\begin{array}{l}\text { Number of units leading to } \\
\text { economic and environmental } \\
\text { benefits (RU5b) }\end{array}$ & Hives managed for pollination services & 3 & & $\sqrt{ }$ & & $\sqrt{ }$ & \\
\hline $\begin{array}{l}\text { Distinctive characteristics } \\
\text { (RU6) }\end{array}$ & $\begin{array}{l}\text { Colouring / numbering of hives aiming identifying individual } \\
\text { loads }\end{array}$ & 2 & $\sqrt{ }$ & $\sqrt{ }$ & $\sqrt{ }$ & $\sqrt{ }$ & $2,9,11,12$ \\
\hline Distinctive markings (RU6a) & Marking beehives with brand code & 3 & $\sqrt{ }$ & $\sqrt{ }$ & & $\sqrt{ }$ & \\
\hline $\begin{array}{l}\text { Spatial and Temporal } \\
\text { distribution (RU7) }\end{array}$ & Beehive migration patterns & 2 & $\sqrt{ }$ & $\sqrt{ }$ & $\sqrt{ }$ & $\sqrt{ }$ & $2,9,11,12$ \\
\hline Spatial patchiness (RU7a) & Hive migration on fragmented landscape & 3 & $\sqrt{ }$ & $\sqrt{ }$ & & $\sqrt{ }$ & 18 \\
\hline Temporal patchiness (RU7b) & Hive migration following phenology and patchy flowering & 3 & $\sqrt{ }$ & $\sqrt{ }$ & & $\sqrt{ }$ & 18 \\
\hline Interactions (I) & Key activities and processes in beekeeping & 1 & $\sqrt{ }$ & $\sqrt{ }$ & $\sqrt{ }$ & $\sqrt{ }$ & 9,11 \\
\hline Harvesting (I1) & Quantity of honey harvested & 2 & $\sqrt{ }$ & $\sqrt{ }$ & $\sqrt{ }$ & $\sqrt{ }$ & $2,9,11,12$ \\
\hline
\end{tabular}




\begin{tabular}{|c|c|c|c|c|c|c|c|}
\hline $\begin{array}{l}\text { Harvesting levels of different } \\
\text { resource users (I1a) }\end{array}$ & Quantity of honey harvested by different beekeepers & 3 & $\sqrt{ }$ & $\sqrt{ }$ & $\sqrt{ }$ & $\sqrt{ }$ & 2 \\
\hline $\begin{array}{l}\text { Harvesting levels from } \\
\text { different locations (I1b) }\end{array}$ & Quantity of honey harvested from different forage locations & 3 & $\sqrt{ }$ & $\sqrt{ }$ & $\sqrt{ }$ & $\sqrt{ }$ & 14 \\
\hline Information sharing (I2) & Methods of information sharing among beekeepers & 2 & $\sqrt{ }$ & $\sqrt{ }$ & $\sqrt{ }$ & $\sqrt{ }$ & $2,9,11,12$ \\
\hline $\begin{array}{l}\text { Information sharing within } \\
\text { formal resource user } \\
\text { organization ( } 12 \mathrm{a})\end{array}$ & Information sharing within formal beekeeper groups & 3 & & $\sqrt{ }$ & $\sqrt{ }$ & $\sqrt{ }$ & \\
\hline $\begin{array}{l}\text { Information sharing within } \\
\text { informal resource user groups } \\
\text { (I2b) }\end{array}$ & Information sharing among informal beekeeper groups & 3 & & $\sqrt{ }$ & $\sqrt{ }$ & $\sqrt{ }$ & \\
\hline $\begin{array}{l}\text { Information sharing between } \\
\text { resource user organization } \\
\text { and government } \\
\text { organizations (I2c) }\end{array}$ & $\begin{array}{l}\text { Information sharing between government and industry } \\
\text { organization }\end{array}$ & 3 & & $\sqrt{ }$ & $\sqrt{ }$ & $\sqrt{ }$ & \\
\hline Deliberation process (I3) & $\begin{array}{l}\text { Presence of organizational structure for beekeepers' } \\
\text { participation in decision making process }\end{array}$ & 2 & $\sqrt{ }$ & $\sqrt{ }$ & $\sqrt{ }$ & $\sqrt{ }$ & $2,9,11,12$ \\
\hline Conflicts (I4) & $\begin{array}{l}\text { Presence of existing conflicts among beekeepers and between } \\
\text { beekeepers and other actors }\end{array}$ & 2 & $\sqrt{ }$ & $\sqrt{ }$ & $\sqrt{ }$ & $\sqrt{ }$ & $2,9,11,12$ \\
\hline $\begin{array}{l}\text { Conflicts among resource } \\
\text { users (I4a) }\end{array}$ & Presence of conflicts among beekeepers & 3 & & $\sqrt{ }$ & & $\sqrt{ }$ & \\
\hline $\begin{array}{l}\text { Conflicts between resource } \\
\text { users and other actors (I } 4 \mathrm{~b})\end{array}$ & $\begin{array}{l}\text { Presence of existing conflicts between beekeepers and other } \\
\text { actors including government organizations }\end{array}$ & 3 & & $\sqrt{ }$ & $\sqrt{ }$ & $\sqrt{ }$ & \\
\hline Investment activities (I5) & Investment for improving and managing bee resources & 2 & $\sqrt{ }$ & $\sqrt{ }$ & $\sqrt{ }$ & $\sqrt{ }$ & $2,9,11,12$ \\
\hline $\begin{array}{l}\text { Investment in resource } \\
\text { improvement and } \\
\text { management }(\mathrm{I} 5 \mathrm{a})\end{array}$ & Investment in resource improvement schemes & 3 & & $\sqrt{ }$ & $\sqrt{ }$ & $\sqrt{ }$ & \\
\hline $\begin{array}{l}\text { Investment in industry } \\
\text { relevant research and } \\
\text { development activities (I5b) }\end{array}$ & Investment in research and development activities & 3 & & $\sqrt{ }$ & $\sqrt{ }$ & $\sqrt{ }$ & \\
\hline Lobbying activities (I6) & Presence of influential beekeepers & 2 & $\sqrt{ }$ & $\sqrt{ }$ & $\sqrt{ }$ & $\sqrt{ }$ & $2,9,11,12$ \\
\hline Self-organizing activities (I7) & $\begin{array}{l}\text { Internal rules made by beekeepers for resource extraction and } \\
\text { management }\end{array}$ & 2 & $\sqrt{ }$ & $\sqrt{ }$ & $\sqrt{ }$ & $\sqrt{ }$ & $2,9,11,12$ \\
\hline
\end{tabular}




\begin{tabular}{|c|c|c|c|c|c|c|c|}
\hline Networking activities (I8) & $\begin{array}{l}\text { Networking and partnership activities among and outside } \\
\text { beekeeper groups }\end{array}$ & 2 & $\sqrt{ }$ & $\sqrt{ }$ & $\sqrt{ }$ & $\sqrt{ }$ & $2,9,11,12$ \\
\hline Monitoring activities (I9) & Monitoring activities on the use and management of resources & 2 & $\sqrt{ }$ & $\sqrt{ }$ & $\sqrt{ }$ & $\sqrt{ }$ & $2,9,11,12$ \\
\hline $\begin{array}{l}\text { Resource use monitoring } \\
\text { activities (I9a) }\end{array}$ & Activities for monitoring bee resources & 3 & & $\sqrt{ }$ & & $\sqrt{ }$ & \\
\hline $\begin{array}{l}\text { Resource unit monitoring } \\
\text { activities (I9b) }\end{array}$ & Beehive monitoring activities & 3 & & $\sqrt{ }$ & & $\sqrt{ }$ & \\
\hline Evaluation Activities (I10) & $\begin{array}{l}\text { Process of evaluation of resource condition and management } \\
\text { initiatives }\end{array}$ & 2 & $\sqrt{ }$ & $\sqrt{ }$ & $\sqrt{ }$ & $\sqrt{ }$ & $2,9,11,12$ \\
\hline Outcomes $(\mathrm{O})$ & Beekeeping Outcomes (from key activities and processes) & 1 & $\sqrt{ }$ & $\sqrt{ }$ & $\sqrt{ }$ & $\sqrt{ }$ & 9,11 \\
\hline $\begin{array}{l}\text { Socio-economic performance } \\
\text { measure }(\mathrm{O} 1)\end{array}$ & Efficiency, equity and sustainability in apiary production & 2 & $\sqrt{ }$ & $\sqrt{ }$ & $\sqrt{ }$ & $\sqrt{ }$ & $2,9,11,12$ \\
\hline Ecological performance $(\mathrm{O} 2)$ & Biodiversity, resilience and sustainability of the bee resources & 2 & $\sqrt{ }$ & $\sqrt{ }$ & $\sqrt{ }$ & $\sqrt{ }$ & $2,9,11,12$ \\
\hline $\begin{array}{l}\text { Externalities to other SES } \\
\text { (O3) }\end{array}$ & Non desired effects that occur as a result of processes & 2 & $\sqrt{ }$ & $\sqrt{ }$ & $\sqrt{ }$ & $\sqrt{ }$ & $2,9,11,12$ \\
\hline Positive externalities (O3a) & Non desired positive effects that occur as a result of processes & 3 & $\sqrt{ }$ & $\sqrt{ }$ & $\sqrt{ }$ & $\sqrt{ }$ & 2 \\
\hline Plant pollination (O3ai) & $\begin{array}{l}\text { Unpaid plant pollination as a result of beehive migration } \\
\text { process }\end{array}$ & 4 & & $\sqrt{ }$ & $\sqrt{ }$ & $\sqrt{ }$ & \\
\hline $\begin{array}{l}\text { Packaged industries (O3aii) } \\
\text { e.g. ecotourism, }\end{array}$ & $\begin{array}{l}\text { Innovative industry model inspired from social-ecological } \\
\text { benefits }\end{array}$ & 4 & & $\sqrt{ }$ & $\sqrt{ }$ & $\sqrt{ }$ & \\
\hline Negative externalities $(\mathrm{O} 3 \mathrm{~b})$ & Non desired negative effects that occur as a result of processes & 3 & $\sqrt{ }$ & $\sqrt{ }$ & $\sqrt{ }$ & $\sqrt{ }$ & 2 \\
\hline $\begin{array}{l}\text { Resource competition with } \\
\text { other species (O3bi) }\end{array}$ & Resource competition with other nectarivorous animals & 4 & $\sqrt{ }$ & $\sqrt{ }$ & $\sqrt{ }$ & $\sqrt{ }$ & 4,8 \\
\hline Disease transmission (O3bii) & Potential for disease transmission & 4 & $\sqrt{ }$ & $\sqrt{ }$ & $\sqrt{ }$ & $\sqrt{ }$ & 3 \\
\hline Related ecosystems (ECO) & Other related ecosystems & 1 & $\sqrt{ }$ & $\sqrt{ }$ & $\sqrt{ }$ & $\sqrt{ }$ & 9,11 \\
\hline Climate pattern (ECO1) & Climate change or other biophysical change in the system & 2 & $\sqrt{ }$ & $\sqrt{ }$ & $\sqrt{ }$ & $\sqrt{ }$ & $2,9,11,12$ \\
\hline Pollution pattern (ECO2) & Presence of toxic chemicals or materials & 2 & $\sqrt{ }$ & $\sqrt{ }$ & $\sqrt{ }$ & $\sqrt{ }$ & $2,9,11,12$ \\
\hline
\end{tabular}




\begin{tabular}{|c|c|c|c|c|c|c|c|}
\hline $\begin{array}{l}\text { Flows in and out of SES } \\
(\text { ECO3) }\end{array}$ & Flows into and out of the focal SES & 2 & $\sqrt{ }$ & & $\sqrt{ }$ & $\sqrt{ }$ & $2,9,11,12$ \\
\hline $\begin{array}{l}\text { Social, economic, and } \\
\text { political settings }(\mathrm{S})\end{array}$ & $\begin{array}{l}\text { Social, economic and political settings in which focal SES is } \\
\text { located in }\end{array}$ & 1 & $\sqrt{ }$ & $\sqrt{ }$ & $\sqrt{ }$ & $\sqrt{ }$ & 9,11 \\
\hline Economic development (S1) & Economic growth of the area & 2 & $\sqrt{ }$ & $\sqrt{ }$ & $\sqrt{ }$ & $\sqrt{ }$ & $2,9,11,12$ \\
\hline Demographic trend (S2) & Population growth and trends & 2 & $\sqrt{ }$ & $\sqrt{ }$ & $\sqrt{ }$ & $\sqrt{ }$ & $2,9,11,12$ \\
\hline Political Stability (S3) & Regulatory framework of the region & 2 & $\sqrt{ }$ & $\sqrt{ }$ & $\sqrt{ }$ & $\sqrt{ }$ & $2,9,11,12$ \\
\hline $\begin{array}{l}\text { Other governance system } \\
\text { (S4) }\end{array}$ & Traditional tenure or other government policies & 2 & $\sqrt{ }$ & $\sqrt{ }$ & $\sqrt{ }$ & $\sqrt{ }$ & $2,9,11,12$ \\
\hline Markets (S5) & Environmental awareness and market demand & 2 & $\sqrt{ }$ & $\sqrt{ }$ & $\sqrt{ }$ & $\sqrt{ }$ & $2,9,11,12$ \\
\hline Media organizations (S6) & Number, diversity and freedom of private and public media & 2 & $\sqrt{ }$ & $\sqrt{ }$ & $\sqrt{ }$ & $\sqrt{ }$ & $2,9,11,12$ \\
\hline Technology (S7) & Presence of relevant technology & 2 & $\sqrt{ }$ & $\sqrt{ }$ & $\sqrt{ }$ & $\sqrt{ }$ & $9,11,12$ \\
\hline
\end{tabular}

$\dagger$ Method column represent different methods used for stakeholder involvement: L - Literature research, I - Semi-structured interviews, O Open ended discussion, $\mathrm{W}-$ Workshop with retired beekeepers.

$\ddagger$ Numbers corresponds to the sources listed below.

\section{Sources}

1. Coh-Martínez, M. E., W. Cetzal-Ix, J. F. Martínez-Puc, S. K. Basu, E. Noguera-Savelli and M. J. Cuevas 2019. Perceptions of the local beekeepers on the diversity and flowering phenology of the melliferous flora in the community of Xmabén, Hopelchén, Campeche, Mexico. Journal of Ethnobiology and Ethnomedicine 15: 16.

2. Delgado-Serrano, M. D. M., \& Ramos, P. 2015. Making Ostrom's framework applicable to characterise social ecological systems at the local level. International Journal of the Commons 9: 808-830.

3. Gordon, R., N. Bresolin-Schott and I. J. East 2014. Nomadic beekeeper movements create the potential for widespread disease in the honeybee industry. Aust Vet J 92: 283-90.

4. Henry, M. and G. Rodet 2018. Controlling the impact of the managed honeybee on wild bees in protected areas. Scientific Reports 8: 9308. 
5. Hinkel, J., M. E. Cox, M. Schlüter, C. R. Binder and T. Falk 2015. A diagnostic procedure for applying the social-ecological systems framework in diverse cases. Ecology and Society 20.

6. Maderson, S. and S. Wynne-Jones 2016. Beekeepers' knowledges and participation in pollinator conservation policy. Journal of Rural Studies 45: 88-98.

7. Malkamäki, A., A. Toppinen and M. Kanninen 2016. Impacts of land use and land use changes on the resilience of beekeeping in Uruguay.

8. Mallinger, R. E., H. R. Gaines-Day and C. Gratton 2017. Do managed bees have negative effects on wild bees?: A systematic review of the literature. PloS one 12: e0189268.

9. Mcginnis, M. D. and E. Ostrom 2014. Social-ecological system framework: initial changes and continuing challenges. Ecology and Society 19.

10. Nolan, M. P. T. and K. S. Delaplane 2016. Distance between Honey Bee Apis mellifera Colonies Regulates Populations of Varroa destructor at a Landscape Scale. Apidologie 2016: 1-9.

11. Ostrom, E. 2009. A General Framework for Analyzing Sustainability of Social-Ecological Systems. Science2 325: $419-422$.

12. Partelow, S. 2018. A review of the social-ecological systems framework: applications, methods, modifications, and challenges. Ecology and Society 23.

13. Phillips, C. 2014. Following beekeeping: More-than-human practice in agrifood. Journal of Rural Studies 36: 149-159.

14. Pilati, L. and P. Fontana 2018. Sequencing the Movements of Honey Bee Colonies between the Forage Sites with the Microeconomic Model of the Migratory Beekeeper. Apiculture. IntechOpen.

15. Pilati, L. and M. Prestamburgo 2016. Sequential Relationship between Profitability and Sustainability: The Case of Migratory Beekeeping. Sustainability 8: 94.

16. Somerville, D. C. and D. Nicholson 2005. The primary melliferous flora and other aspects associated with beekeeping within State forests of New South Wales as determined by surveys of beekeepers. Australian Forestry 68: 9-16.

17. Van Dijk, J., J. Gomboso and C. Levantis 2016. Australian honey bee industry: 2014-15 survey results, Canberra.

18. Vogt, J. M., G. B. Epstein, S. K. Mincey, B. C. Fischer and P. McCord 2015. Putting the "E" in SES: unpacking the ecology in the Ostrom social-ecological system framework. Ecology and Society 20.

19. https://www.legislation.wa.gov.au (with search of keywords beekeeper and bee keeping, honey)

20. https://www.legislation.wa.gov.au (with search of keywords apiary, honey)

21. https://www.legislation.wa.gov.au (with search of keywords honey, honey extraction)

22. Beekeeping and land management, preceedings of a workshop, November 4, 1985. Perth Australia, Department of Conservation and Land Management (CALM) (hardcopy)

23. Commercial beekeeping in Australia report https://www.agrifutures.com.au/wp-content/uploads/publications/07-059.pdf

24. General conditions for using apiary authority on crown land, Department of Parks and Wildlife July 2013. https://www.dpaw.wa.gov.au/images/documents/plants-

animals/animals/general_conditions_for_using_apiary_authorities_on_crown_land_in_western_australia.pdf

25. Australian honey bee industry: $2006-07$, Rural Industries Research and Development Corporation (RIRDC) (hard copy)

26. https://ablis.business.gov.au/service/wa/apiary-authority/16958 
Appendix 2. Interview Themes

\section{Interview Themes: Beekeepers}

\section{Migratory beekeeping}

1. Number of hives in operation

2. Involvement in beekeeping

3. Hive management practices

4. Technology use

5. Factors considered for deciding forage location for hive migration

6. Factors affecting hive migration decisions

7. Governance in beekeeping systems

\section{Market value of the apiary products}

8. Decisions around price of products and factors influencing price

9. Cost associated with beekeeping

10. Aspirations of expanding business

\section{Knowledge of Environmental Resources}

11. Key target flora

12. A "good honey flow" and influencing factors

13. Predictability of spatial-temporal availability of a good flow

\section{Identifying pressures on the industry}

14. Factors influencing spatial-temporal availability of flowering events

15. Effects of beekeeping on the landscape

16. Any issues effecting the industry

\section{Knowledge of the human-environment system}

17. Understanding around key components from humans and the environment comprising the beekeeping system 


\section{Questions for all organisations:}

1. Levels of interaction with commercial beekeepers

2. Frequency of interaction with the WA bee industry

3. Role of the organization in WA bee industry

4. Key issues impacting the health and growth of the WA bee industry

\section{Questions for permitting organisations:}

5. Required permits for beekeeping in WA and process to obtain the permits

6. Rules governing the access to resources

7. Issues associated with resource access

\section{Questions for land/resource management organisations:}

8. Involvement with the industry

9. Current and previous resources management practices

10. Key issues associated with bee related land/resource management and the ways to deal with the issues 